\title{
Bilim ve Sanat Merkezlerindeki Öğrencilerin Müzik Dersinde Karşılaştıkları Sorunlar ve Derse Yönelik Tutumlarının İncelenmesi*
}

\section{An Analysis on the Problems Encountered by Students in Music Class in Science and Art Centers and Their Attitudes towards The Course \\ Gökalp Parasız}

Doç. Dr., Balıkesir Üniversitesi, Necatibey Eğitim Fakültesi, Güzel Sanatlar Eğitimi Bölümü, Müzik Eğitimi Anabilim Dalı email: gokalp.parasiz@balikesir.edu.tr (DORCID ID: https://orcid.org/0000-0002-9349-0293

\section{Elçin Arslan Kaya}

Öğretmen, Antalya Manavgat Şehit Uğur Yıldız İmam Hatip Ortaokulu email: elcinarslan0101@gmail.com (DORCID ID: https://orcid.org/0000-0002-0598-872X

* Bu çalışma, "Bilim ve Sanat Merkezlerindeki Öğrencilerin Müzik Dersinde Karşılaştıkları Problemler ile Müzik Dersine Yönelik Tutumlarının Çeşitli Değişkenlere Göre İncelenmesi” isimli yüksek lisans tezinden türetilmiştir.

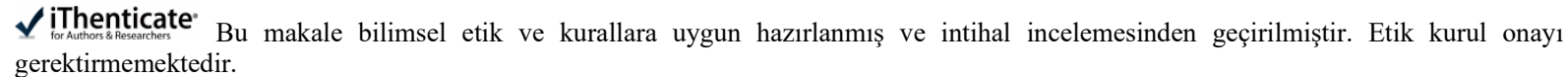

Atıf (APA 6)/To cite this article

Parasız, G., \& Arslan Kaya, E. (2021). Bilim ve sanat merkezlerindeki öğrencilerin müzik dersinde karşılaştıkları sorunlar ve derse yönelik tutumlarının incelenmesi. Atatürk Üniversitesi Güzel Sanatlar Enstitüsü Dergisi, 27(46), 101-120. https://doi.org/10.35247/ataunigsed.843035

Makale Gönderim Tarihi/Received: 18/12/2020

Makale Kabul Tarihi/Accepted: 29/01/2021

Makale Yayın Tarihi/Published: 29/03/202

Research Aricle/Araştırma Makalesi

$\ddot{O} z$

Bu araştırmanın amacı, Antalya ili ve Alanya ilçesi Bilim ve Sanat Merkezi'nde müzik eğitimi görmekte olan üstün yetenekli çocukların müzik dersine karșı tutumlarını çeșitli değişkenler üzerinden değerlendirmektir. Araştırma, betimsel türde ve genel tarama modelindedir. Öncelikle, arastırmanın problem durumuna yönelik alanyazın taraması yapılmıştır. BSM'lerde, müzik dersleri konuları kapsamında öğretmenlerin derslerinde hangi öğretim yöntemlerini kullandıklarını belirlemek üzere, görüşme formu uygulanmış ve sonuçlar analiz edilmiștir. Yapılacak olan uygulamalar için, öğrenciler, müzik derslerine ilgilerinin tespitine yönelik geliştirilen tutum ölçeği testine tabi tutulmuştur. Yaş, cinsiyet ve sınıf değişkenlerine göre öğrencilerden elde edilen verilerin istatistiksel analizleri yapılmıștır. Ayrıca tutum puanlarının ve anket cevaplarının dağılımları için frekans (f) ve yüzde (\%) değerleri kullanılmıștır. Araștırmaya katılan öğrencilerin çoğunluğunu kız öğrencilerin oluşturduğu, en çok katılımın 5. Sinıflardan ve en yoğun yas grubunun 11 yaș grubundaki öğrencilerden oluştuğu belirlenmiștir. Öğrencilerin BSM'leri çoğunlukla kendilerinin tercih ettiği, müzik derslerine karșı tutumlarının da olumlu yönde olduğu belirlenmiștir. Bilim Sanat Merkezi ve normal okullardaki müzik dersi konularının birbirinden farklılık gösterdiği, BSM'de müzik dersinin ve enstrüman eğitiminin daha detaylı öğrenildiği, sınıfların fiziki şartlarının yeterli olduğu, ögrencilerin enstrüman çalma ve öğrenmede herhangi bir güclük cekmediği sonuc olarak tespit edilmiştir. Öğrencilerin cinsiyet, sınıf ve yaş değişkenlerine göre müzik dersine karșı tutumları değerlendirilmiștir. Öğrencilerin cinsiyet değişenine göre müzik dersi tutum puanlarının değişmediği belirlenmiştir. Sınıf değişkenine göre 8 . ve 2 . sınıfların müzik dersine karșı tutumlarının diğer sınıflara göre yüksek olduğu tespit edilmiştir. Yaş değişsenine göre 8,15 ve 16 yaş gruplarının müzik dersine karşı tutumlarının diğer yaş gruplarına göre daha yüksek olduğu sonuçları elde edilmiștir.

Anahtar kelimeler: Müzik Eğitimi, Bilim ve Sanat Merkezi, Üstün Yetenekli Cocuklar

\begin{abstract}
This study aims to assess the attitudes of talented children who study music in the Science and Arts Center in Alanya District of Antalya Province, based on various variables. The research is a descriptive study. In the study, the general survey method was used. First of all, the literature was searched in terms of the problem situation of the research. Interview form was applied to determine which teaching methods the teachers used in their courses within the scope of topics of music courses in Science and Arts Centres and the results were analyzed. For the applications, the students were subjected to the attitude scale test developed to determine their interest in music courses. Statistical analysis of the data obtained from the students according to age, gender, and class variables was done. Also, frequency (f) and percentage (\%) values were used for the distribution of attitude scores and questionnaire responses. It was determined that the majority of the students who participated in the study were female students, and the highest participation rate was composed of 5th-grade students and the most intensive age group consisted of 11-year-old students. It was determined that, mostly, the students preferred SAC themselves and their attitudes towards music courses were positive. It was determined that the subjects of music courses between Science and Art Centres and other schools differed from each other. Also, music courses and instrument education were understood in more detail, the physical conditions of the classes were sufficient, and students did not have any difficulty in playing and learning how to play instruments in SAC. Students' attitudes towards music courses were evaluated according to gender, class, and age variables. It was determined that students' attitude scores for the music course did not change according to gender. According to the class variable, the attitudes of 8 th and 2nd-grade students towards music courses were higher than the other grades. According to the age variable, it was obtained that the attitudes of 8,15 , and 16 age groups towards music courses were higher than the other age groups.
\end{abstract}

Keywords: Music Education, Science and Art Centre, Talented Children 


\section{Giriş}

İnsan, doğumundan ölümüne kadar sürekli bir öğrenme faaliyeti içerisindedir. Öğrenme içgüdüsü ile doğan tüm insanlar, hayatları boyunca bu süreçte yer almaktadırlar. Ĕgitimin genel tanımına baktığımızda ise bireylerin yaşamı boyunca kendi öğrenme isteği ya da çevrenin etkisi ile öğrenme ortamı içerisinde olduğunu söylenebilir. Nasıl ki yemek, içmek zaruri bir ihtiyaçsa, eğitim de bireylerin gelişmesi için çok önemli bir ihtiyaçtır. Ergün (2014, s. 2) eğitimi, insan doğasına ait yatkınlıkları büyüme ve olgunlaşma evresinde uyararak pozitif yönde desteklemek şeklinde yorumlamıştır. Bu yoruma baktığımızda eğitimin çevre ile etkisi söz konusudur. Çevre ne kadar iyi düzenlenirse, öğrenmede o kadar iyi olur ve birey, kendisini en iyi şekilde ifade etmeyi ögrenir.

İnsanlar, ait oldukları toplum içerisinde, iletişim ve paylaşım yoluyla bir arada yaşayabilmiş ve gelişerek medeniyetler kurup tarihte iz bırakabilmişlerdir. Bu durumun gerçekleşmesi ve sürdürülebilmesinde en büyük ortak paydalardan birisini daima eğitim oluşturmuştur. Geçkil $(2012$, s. 1), bazı toplumların bulundukları çağlara göre daha ileri medeniyetler kurduklarını ve bu sayede başka toplulukları etkileyip onlara liderlik yaptıklarını belirtmiş ve medeniyetlerini koruyabilen toplulukların ortak noktalarının ise eğitim olduğunu vurgulamıștır. Toplumlar kendilerine uygun insanı kendilerine özgü eğitim süreci içinde yetiştirirler. Bu nedenle, onu tesadüflere ve kültürlemenin gelişigüzel etkilerine açık bırakmamışlardır. Toplumlar insanlara birlikte yaşamanın gerektiğini, toplum bilincini vermek için eğitim sürecinin amaçlarını ve içeriğini belirlemiş ve onu kontrol altına almışlardır (Fidan, 2012, s. 6).

Bu noktada tüm toplumlar, günün idare ve yönetim şekline bağlı resmi veya özel kanallarla, belirli kademelerde eğitim vermeye yönelik farklı içerik ve özellikte eğitim-öğretim programları oluşturdukları okullar açarak eğitimi planlamışlardır. Açıkalın (2009, s. 30) 'Okul' olarak adlandırılan bu kurumların, çocukların topluma yararlı olabilmeleri için gerekli davranış, bilgi ve becerilerin kazandırılmaya çalışıldığı bir ortam ve öğrenciyi hayata hazırlayan toplumsal bir kurum olduğunu vurgulamaktadır. Ayrıca bu okulların eğitim-öğretim programlarından farklı olarak, özel eğitim gerektiren çocukların ihtiyaçlarına göre düzenlenmiş okullar da bulunmaktadır. Aynı zamanda üstün zekalı ve üstün yetenekli çocukların eğitimini desteklemek ve onların ihtiyaçlarına cevap verebilmek adına da yine onlara özel okullar dizayn edilmiştir.

Olaylara ve durumlara herkesin yaklaşımından farklı, akılcı, pratik ve yaratıcı fikirler sunan bireyler, toplumda üstün zekâlı veya üstün yetenekli insanlar olarak isimlendirilmiştir. $\mathrm{Bu}$ insanlar yaşantılarıyla ve davranış biçimleriyle daima farklı olmuş ve farklılıklar oluşturmuştur. Üstün zekâlı ve üstün yetenekli bireylerin küçük yaşlarda tespit edilip, özelliklerine ve ihtiyaçlarına göre eğitim verilmesi büyük önem arz etmektedir. Sakar ve Maba (2015, s. 111), toplumların gelişiminde bireysel olarak üstün özelliklere sahip bireylerin çoğunlukla ön planda olduklarını ve bu bireyleri fark edip sahiplenen toplumların bilim, sanat, spor ve diğer alanlarda daha fazla gelişim ve ilerleme kaydettiklerini belirtmişlerdir. Tarih boyunca milletlerin, eğitim anlayışları, modelleri hep değişmiş fakat üstün yeteneklilerin yetiştirilmesi gereği hiçbir zaman değişmemiştir. Aristo'nun seçkinler eğitiminden ortaçă̆ Avrupa'sındaki seçkinler eğitimine, Osmanlılarda Enderunlardan, günümüze hep üstün yeteneklilerin eğitimi toplumlar ve milletler için önemli ve farklı olmuştur (Yıldız, 2010, s. 1).

Üstün yetenekli öğrencilerin eğitim süreçlerinde, ortak yürütülen eğitim-öğretim programlarının yanında onların eğitimini destekleyici nitelikte oluşturulmuş bireyselleştirilmiş eğitim programları ve çeşitli öğretim modellerinin kullanılması ile bu öğrencilerin gelişimlerindeki hızın ve niteliğin olumlu yönde etkilediği bilinen bir durumdur. Erişti (2012, s. 21-22), üstün yetenekli öğrencilerin öğrenme ve öğretme olgularına yükledikleri anlamların bilinmesinin, onlar için nitelikli öğrenme ortamlarının geliştirilmesinin, akademik başarısızlıklarının önlenmesini, öğrenmeye dönük ilgilerinin ve güdülenmelerinin sağlanmasını, geliştirilecek öğretim programlarının ve öğretim etkinliklerinin niteliği ile sağlanabileceğini vurgulamaktadır. Yağlı (2011, s. 5), ülkemizde farklı bir cevher olarak kabul ettiğimiz, üstün ve özel yetenekli çocuklarımızın geleceği için, en iyi eğitim modelini uygulayabilecek kurumun oluşturulmasının önemini ve eğitim politikalarında yer almasının zorunluluğunu belirtmiştir.

Üstün Yetenekli Öğrencilerin, normal eğitim sistemi içerisinde okullarda gördükleri eğitim, bu öğrencilerin ihtiyaçlarını yeterli düzeyde karşılayamayacağı için onlara okul saatleri dışında, kapsamlı ve bireyselleştirilmiş eğitim programları sunmak ve eğitimlerini bu yönde gerçekleştirmek, öğrencilerin gelişebilmeleri açısından gereklilik ve önem arz etmektedir. Bilim ve Sanat merkezleri, bu öğrencilerin eğitimini en iyi ş̧ekilde üstlenmekte ve onları geleceğe hazırlamakta oldukça önemli bir role sahiptir. Millî Eğitim Bakanlığg'na bağlı normal okulların eğitim programları dahilinde bu durumun karşılanabilmesi zaman ve fiziki şartlar bakımından oldukça güç olduğu için, özel derslere ve fiziki imkânlara ihtiyaç duyulmaktadır. Bundan dolayı, MEB' e bağlı olarak, üstün yetenekli çocuklar için 'Bilim ve Sanat Merkezleri' açılmıştır. Bilim ve Sanat Merkezleri öğrencilerin okul saatleri dişında eğitim-öğretim gördükleri kurumlardır.

$\mathrm{Bu}$ kurumlar öğrencilerin ilgi ve yeteneklerine uygun olarak farklı alanlarda farklı düzeylerde kendilerini geliştirebilmelerine ortam hazırlamaya çalışır (Çamdeviren, 2014, s. 2). Bu merkezlerde üstün yetenekli öğrenciler bireyselleştirilmiş eğitim programlarıyla çeşitli yetenek alanlarında kendilerini geliştirebilmektedir. Böylelikle bu özellikteki öğrencilerin yaşıtlarından bir ölçüde bağımsız olarak gruplara ayrılması ve normal eğitimden farklı 
eğitime tabi tutulması mümkün olabilmektedir (Bakioğlu ve Levent, 2013, s. 41). Bu öğrenciler örgün eğitimlerine paralel olarak BSM'lerde üstün oldukları yetenek alanında diğer okullardan gelen üstün yetenekli arkadaşlarıyla ve alan öğretmenleriyle birlikte çalışabilmektedirler (Özer Keskin, Keskin Samancı ve Aydın, 2013, s. 82).

Üstün yeteneğin ön plana çıktığı birçok alandan birisi de müziktir. İster yeteneğiniz olsun ister olmasın müzik insan hayatının vazgeçilmez bir parçasıdır.

Müzik yeteneği, çok erken yaşlarda keşfedilebilen bir yetenek türüdür. Ailelerin ve çevrenin çocuklardaki müzik yeteneğini keşfetmeleri süreci genellikle çocuğun dinlediği müziğe yaptığı eşlik ve gösterdiği tepkilerle başlar. Devamında ise, uzman kişilere başvurularak onlardan görüş alınır ve yönlendirmeler yapılır. Bu süreç oldukça uzun süren, sabır ve destek isteyen ayrıca motivasyon gerektiren bir süreçtir.

Müzik alanında üstün yetenekli öğrencilerin özelliklerini (Tunçdemir, 2004) genel olarak; ritim ve melodiye diğer öğrencilerden daha fazla duyarlı olduklarını, müzik etkinliklerine katılmayı ve müziğe dair her şeyin ilgilerini çektiği, duygularını müzikle ifade etmekten hoşlandıklarını, sesleri notalarıyla çıkarıp melodi ve ritimleri kolay bir şekilde tekrar edebildiklerini ve enstrüman çalmaya son derece yatkın olduklarını belirtmiştir.

Müzik yeteneği genellikle diğer çeşit becerilerden daha erken gelişen bir yapıya sahiptir. Bu beceri 1 ya da 2 yaşında ortaya çıkar. Büyük keman virtüözlerinin \%70’i bu çocuk yeteneklerdendir- örneğin Wolfgang Mozart ve Yehudi Menuhin bu çocuk yeteneklerden sayılmaktadır. Böyle bir yeteneğin işareti çocuğun çok küçük yaşta müziğin büyüsüne kapıldıklarının gözlemlenmesidir. Müzik konusunda doğuştan yetenekli bir çocuk içgüdüsel olarak müzik yapısını anlar, harmoni ve ritim duygusunu içinde taşır (Davis, 2014, s. 65).

Çocukların müzik yeteneğinin belirlenmesinde pek çok değişken söz konusudur. Çocuk yaşlarda genellikle müzik kulağına sahip olma durumu öncelikle ele alınır ve yaş gruplarına göre yaklaşımlar belirlenir. Çeşitli testlerle ölçülen işitme yeteneği dişında, hangi enstrümana yönlendirileceği de çocuğun yeteneği ve tercihiyle doğru orantılıdır. Müzik yeteneğinin belirlenmesi ve eğitim süreçlerinde sahip olunan imkânlar örgün ve yaygın eğitim kurumları ve özel derslerle sağlanabilmektedir. MEB'e bağlı okullarda ileri düzeyde müzik yeteneğine sahip olan öğrenciler genellikle müzik öğretmenleri tarafından keşfedilmekte ve aileleri ile iletişime geçilerek bu alana yönlendirilebilmektedir.

MEB'e bağlı olan BSM'ler, özel yetenekli çocukların eğitimine önem vermekte ve onların okul saatleri dışında kendilerini geliştirebilecekleri ortamları sağlamaktadır. Fen bilimleri ve matematik eğitiminin yanı sıra sanat eğitiminin de yer aldığı ders programlarında öğrenciler, müzik alanında çalgı eğitimi, nota bilgisi dersleri almakta ve sosyal aktivitelerde bulunmaktadırlar. Buradan hareketle çalışmanın amacı; Bilim ve Sanat Merkezleri müzik dersi eğitim programlarının içeriğini ve kapsadığı alanları, dersin işlenişine yönelik farklı öğretim yöntemlerinin kullanılma durumlarını, öğrencilerin müzik dersine ilgilerinin ve derslerde karşılaştıkları sorunların neler olduğunu ve müzik derslerine yönelik tutumlarını yaş, cinsiyet ve sınıf değişkenine göre ele almaktır. Bu doğrultuda araştırmanın alt amaçları aşağıdaki şekilde belirlenmiştir:

1. Bilim ve Sanat Merkezlerinde müzik dersleri ve konuları kapsamında öğretmenlerin uyguladıkları farklı öğretim yöntemleri nelerdir?

2. Bilim ve Sanat Merkezlerinde öğrencilerin müzik derslerine ilgileri nasıldır?

3. Bilim ve Sanat Merkezlerinde öğrencilerin müzik derslerinde karşılaştıkları problemler nelerdir?

4. Bilim ve Sanat Merkezlerindeki öğrencilerin tutumları arasında cinsiyet değişkenine göre anlamlı bir farklılık var midir?

5. Bilim ve Sanat Merkezlerinde öğrencilerin tutumları arasında sınıf değişkenine göre anlamlı bir farklılık var midir?

6. Bilim ve Sanat Merkezlerinde öğrencilerin tutumları arasında yaş değişkenine göre anlamlı bir farklılık var midir?

\section{Yöntem}

\subsection{Araştırma Modeli}

Araştırma, betimsel türde ve genel tarama modelindedir. "Genel tarama modelleri, çok sayıda elemandan oluşan bir evrende, evren hakkında genel bir yargıya varmak amacı ile evrenin tümü ya da ondan alınacak bir grup, örnek ya da örneklem üzerinde yapılan tarama düzenlemeleridir" (Karasar, 2005, s. 79).

Betimleme yöntemi ile üstün zekâ ve üstün yetenek kavramlarıyla ilgili alanyazın taraması yapılmış, Türkiye'de Bilim ve Sanat Merkezi adı verilen kurumların ne amaçla açıldığı ve burada eğitim alan üstün yetenekli çocuklar hakkında edinilen bilgilerle, onların müzik dersinde karşılaştıkları problemlerin ve müzik dersine karşı tutumlarının neler olduğuna dair çıkarımlarda bulunulmuştur. Antalya ilinin merkezinde ve ilçesi Alanya'da bulunan BSM'lerde, müzik eğitimi görmekte olan 47 öğrenciye 'anket formu' ve ‘tutum ölçeği', bu iki okulda 
görev yapmakta olan 4 müzik öğretmenine de ‘yarı yapılandırılmış görüşme formu' uygulanmıştır. Bu formlardan elde edilen veriler, istatistiksel yöntemle ayrıntılı bir şekilde analiz edilip yorumlanmıştır.

\section{2. Çalışma Grubu}

Çalışma grubunu, 2018-2019 eğitim öğretim yılında Antalya ili ve Alanya ilçesinde bulunan Bilim ve Sanat Merkezinde eğitim vermekte olan 4 müzik öğretmeni ve 30’u k1z 17'si erkek olmak üzere, ilkokul, ortaokul ve lise düzeyinde müzik eğitimi alan 47 öğrenci oluşturmaktadır.

Araştırma grubu belirlenirken araştırmacıya yakın olduğu için yaşadığı il temel alınmış ve çıkan sonuçların Türkiye'de bulunan diğer Bilim ve Sanat Merkezlerine genellenmesi amaçlanmıştır.

Öğrencilerin demografik bilgileri incelendiğinde sonuçlar aşağıdaki gibi bulunmuştur:

Tablo 1

Öğrencilerin Cinsiyete Göre Dă̆glımı

\begin{tabular}{ccc}
\hline Cinsiyet & Frekans $(\mathrm{f})$ & Yüzde $(\%)$ \\
\hline Erkek & 17 & 36.2 \\
Kız & 30 & 63.8 \\
Toplam & 47 & 100.0 \\
\hline
\end{tabular}

Tablo 1'de görüldüğü gibi araştırmaya katılan öğrencilerin cinsiyet faktörüne göre dağılımlarına bakıldığında toplam 47 öğrenciden 30 kişinin \%63.8 oranla Kız ve 17 kişinin \%36.2 oranla Erkek olduğu görülmektedir. Bu doğrultuda araştırmaya katılan öğrencilerin büyük çoğunluğunun Kız öğrenci olduğu söylenebilir.

Tablo 2

Öğrencilerin Sınıf Düzeyine Göre Dă̆ılımı

\begin{tabular}{ccc}
\hline Sinıf Düzeyi & Frekans $(\mathrm{f})$ & Yüzde (\%) \\
\hline 2. Sinıf & 2 & 4.2 \\
3. Sinıf & 5 & 10.6 \\
4. Sinıf & 7 & 14.9 \\
5. Sinıf & 10 & 21.4 \\
6. Sinıf & 7 & 14.9 \\
7. Sinıf & 5 & 10.6 \\
8. Sinıf & 5 & 10.6 \\
9. Sinıf & 6 & 12.8 \\
\hline Toplam & 47 & 100.0 \\
\hline
\end{tabular}

Tablo 2'de görüldüğü gibi, araştırmaya katılan öğrencilerin sınıf düzeyine bakıldı̆̆ında \%21.4'ünün 5. Sınıf, \%14.9'unun 6. Sinıf, \%12.8'inin 9. Sınıf, ayrı ayrı \%10.6'sının 3., 7. ve 8. Sinıf ve \%4.2'sinin 2. Sinıf olduğu görülmektedir. Tabloda araştırmaya katılan öğrenci sayısına bakıldığında, en çok katılımın 5. Sınıf'tan sağlandığı söylenebilir.

Tablo 3

Öğrencilerin Yaş Değişkenine Göre Dă̆ılımı

\begin{tabular}{cccc}
\hline Yaş & Frekans (f) & Yüzde (\%) \\
\hline 8 & 2 & 4.2 & 14.9 \\
9 & 7 & 12.8 \\
10 & 6 & 23.5 & 14.9 \\
11 & 11 & 8.5 & 10.6 \\
13 & 7 & 8.5 \\
14 & 4 & 2.1 \\
15 & 4 & 100.0 \\
Toplam & 47 & 1 & \\
\hline
\end{tabular}

Tablo 3'te görüldüğü gibi araştırmaya katılan öğrencilerin yaş dağılımına bakıldığında öğrencilerin yaşlarının 816 arasında değiştiği ve en yoğun yaş grubunu 11 yaş grubundaki öğrencilerin oluşturduğu görülmektedir.

\subsection{Veri Toplama Araçları}

Araştırma problemi doğrultusunda, doğrudan ve dolaylı kaynaklara ulaşılarak, problemin çözümüne katk1 sağlayacak verileri toplamak için alanyazın taraması yapılmıştır. Kaynaklar kitap, dergi, makale, tez vb. den oluşmaktadır. Ayrıca internet tabanlı kaynaklar da kullanılmıştır.

\subsubsection{Görüsşme Formu}

Araştırmada verilerin toplanması aşamasında, ilk olarak Bilim Sanat Merkezleri'nde eğitim vermekte olan öğretmenler için 'yarı yapılandırılmış görüşme formu' uygulanmıştır. Antalya ili merkezinde bulunan BSM'de görev yapmakta olan 2, Alanya ilçesinde bulunan BSM'de görev yapmakta olan 2 müzik öğretmenine, "Bilim ve 
Sanat Merkezlerinde yürütmekte olduğunuz müzik derslerinde, kullandığınız öğretim yöntemleri hakkında bilgi verebilir misiniz? Farklı öğretim yöntemleri kullanmakta mısınız?” soruları yöneltilmiştir.

\subsubsection{Anket Formu}

Öğrencilerin müzik dersinde karşılaştıkları problemlere yönelik anket formu uygulanmış, “BSM'de sınıfımızın fiziki şartları yeterli değil, enstrüman çalmakta ve öğrenmekte güçlük çekiyorum, müzik dersleri enstrüman çalmayı öğrenmekle sınırlıdır, BSM’de gördüğümüz müzik dersi ile okulda gördüğümüz müzik dersinin konuları birbirinden farklıdır.” gibi sorular; 5'li Likert tipine uygun 'Kesinlikle Katılmıyorum, Katılmıyorum, Kararsızım, Katılıyorum, Kesinlikle Katılıyorum' seçenekleri ile sunularak uygulanmıştır.

\subsubsection{Tutum Ölçeği}

Antalya ili ve Alanya ilçesinde bulunan Bilim Sanat Merkezleri’nde eğitim görmekte olan öğrencilere müzik derslerine yönelik 'tutum ölçeği’ uygulanmış, 'BSM'de gördüğümüz müzik dersini severim, ilgi çekici bulurum, müzik derslerinde öğretilen eserleri söylemekten hoşlanırım, müzik derslerinin beni kültürel anlamda geliştirdiğine inanırım ve beni sosyalleştireceğini düşünürüm, ileride müzikle ilgili meslek alanını tercih etmek isterim.” gibi sorular; 5'li Likert tipine uygun 'Kesinlikle Katılmıyorum, Katılmıyorum, Kararsızım, Katılıyorum, Kesinlikle Katılıyorum' seçenekleri ile sunularak uygulanmıştır.

\subsection{Geçerlik ve Güvenirlik}

Çalışmada hem tutum ölçeği hem de anket için uzman görüşü alınmıştır. Tutum ölçeği için 24 soruluk, anket için 12 soruluk bir soru havuzu oluşturulmuş, oluşturulan sorular "Gerekli", "Düzeltilmeli" ve "Çıkarılmalı" seçeneklerini içeren bir form ile birlikte 3 kişiden oluşan uzman jüriye sunulmuştur. Uzman değerlendirmeleri sonucunda tutum ölçeğinden 4 soru, anketten ise 2 soru çıkarılarak kapsam geçerliğini sağlayan formlar tutum ölçeği 20 soru, anket 10 soru olacak şekilde oluşturulmuştur. Görüşleri alınan uzman grubunun bilgileri Tablo 4'de gösterilmiştir.

\section{Tablo 4}

Uzman Grubu Bilgileri

\begin{tabular}{clcc}
\hline & & Üniversite/Fakülte/Bölüm & Alan \\
\hline 1 & Atatürk Üniversitesi K.K. Eğitim Fakültesi Müzik Eğitimi Ana Bilim Dalı & Doç. Dr. & Müzik Eğitimi \\
2 & Atatürk Üniversitesi K. K. Eğitim Fakültesi Eğitim Bilimleri Bölümü & Doç. Dr. & Ölçme-Değerlendirme \\
3 & Atatürk Üniversitesi Güzel Sanatlar Fakültesi Müzik Bilimleri Bölümü & Dr. Öğr. Ü. & Müzik Eğitimi \\
\hline
\end{tabular}

Uzman görüşleri alındıktan sonra ölçek ve anketin kapsam geçerliğini sağlayıp sağlamadığı ve ölçek ve ankette kalacak maddelerin tespiti için KGO (Kapsam Geçerlik Oranı) ve KGİ (Kapsam Geçerlik İndeksi) değerleri belirlenmiştir. KGO hesaplamasında aşağıdaki formül kullanılmıştır:

$$
\mathrm{KGO}=\frac{\mathrm{N}_{\mathrm{G}}}{\mathrm{N} / 2}-1
$$

$\mathrm{N}_{\mathrm{G}}$ : Gerekli diyen uzman sayıs1

$\mathrm{N}$ : Araştırmaya katılan toplam uzman sayısı

KGİ hesaplaması ise uygun görülen maddelerin KGO değerlerinin ortalaması hesaplanarak elde edilmiştir. Tablo 5'de, kapsam geçerliğinin sağlanmasında ve elde edilen KGO değerlerinin karşılaştırılmasında kullanılacak KGÖ (Kapsam Geçerlik Ölçütü) değerleri görülmektedir.

\section{Tablo 5}

KGO Karşılaştırması İçin Minimum Değerler

\begin{tabular}{ccc}
\hline Uzman Sayıs & KGÖ \\
\hline 3 & 0.99 \\
5 & 0.99 \\
6 & 0.99 \\
7 & 0.99 \\
8 & 0.78 \\
9 & 0.75 \\
10 & 0.62 \\
11 & 0.59 \\
12 & 0.56 \\
13 & 0.54 \\
14 & 0.51 \\
15 & 0.49 \\
20 & 0.42 \\
25 & 0.37 \\
30 & 0.33 \\
& & 0.31 \\
\end{tabular}

(Veneziano \& Hooper, 1997). 
Tablo 5'e göre, elde edilen KGO değeri, uzman sayısına göre verilen KGÖ değerinden büyükse kapsam geçerliği sağlanmış, küçükse sağlanmamış demektir. Yeşilyurt ve Çapraz’a (2018) göre, elde edilen KGİ değeri KGÖ değerinden büyükse, ölçekte kalan maddeler kapsam geçerliğini sağlamış; elde edilen KGİ değeri KGÖ değerinden küçükse kalan maddeler kapsam geçerliğini sağlamamış anlamına gelmektedir. Uzman görüşleri doğrultusunda belirlenen maddelere yönelik KGO değerleri ve ölçeklerin tamamına ait KGÖ ve KGİ değerleri Tablo 6'da görülmektedir.

Tablo 6

Tutum Ölçeği ve Anket Maddeleri KGO, KGÖ ve KGİ Değerleri

\begin{tabular}{|c|c|c|c|c|c|c|c|c|c|}
\hline \multicolumn{10}{|c|}{ Tutuma Yönelik Maddeler } \\
\hline Madde & Gerekli & Düzeltilmeli & Ç1karılmalı & KGO & Madde & Gerekli & Düzeltilmeli & Çıkarılmalı & $\mathrm{KGO}$ \\
\hline 1 & 3 & 0 & 0 & 1.00 & 13 & 3 & 0 & 0 & 1.00 \\
\hline 2 & 3 & 0 & 0 & 1.00 & 14 & 1 & 0 & 2 & -0.33 \\
\hline 3 & 3 & 0 & 0 & 1.00 & 15 & 2 & 0 & 1 & 0.33 \\
\hline 4 & 3 & 0 & 0 & 1.00 & 16 & 3 & 0 & 0 & 1.00 \\
\hline 5 & 3 & 0 & 0 & 1.00 & 17 & 3 & 0 & 0 & 1.00 \\
\hline 6 & 3 & 0 & 0 & 1.00 & 18 & 5 & 0 & 0 & 1.00 \\
\hline 7 & 3 & 0 & 0 & 1.00 & 19 & 5 & 0 & 0 & 1.00 \\
\hline 8 & 3 & 0 & 0 & 1.00 & 20 & 0 & 0 & 3 & -1.00 \\
\hline 9 & 3 & 0 & 0 & 1.00 & 21 & 5 & 0 & 0 & 1.00 \\
\hline 10 & 3 & 0 & 0 & 1.00 & 22 & 1 & 0 & 2 & -0.33 \\
\hline 11 & 3 & 0 & 0 & 1.00 & 23 & 3 & 0 & 0 & 1.00 \\
\hline 12 & 3 & 0 & 0 & 1.00 & 24 & 3 & 0 & 0 & 1.00 \\
\hline \multicolumn{10}{|c|}{ Anket Maddeleri } \\
\hline Madde & Gerekli & Düzeltilmeli & Gereksiz & $\mathrm{KGO}$ & Madde & Gerekli & Düzeltilmeli & Gereksiz & $\mathrm{KGO}$ \\
\hline 1 & 3 & 0 & 0 & 1.00 & 7 & 3 & 0 & 0 & 1.00 \\
\hline 2 & 3 & 0 & 0 & 1.00 & 8 & 3 & 0 & 0 & 1.00 \\
\hline 3 & 3 & 0 & 0 & 1.00 & 9 & 2 & 0 & 1 & 0.33 \\
\hline 4 & 3 & 0 & 0 & 1.00 & 10 & 3 & 0 & 0 & 1.00 \\
\hline 5 & 3 & 0 & 0 & 1.00 & 11 & 3 & 0 & 0 & 1.00 \\
\hline 6 & 1 & 0 & 2 & 1.00 & 12 & 3 & 0 & 0 & 1.00 \\
\hline \multicolumn{5}{|c|}{ Toplam Uzman Sayıs1 } & \multicolumn{5}{|c|}{3} \\
\hline \multicolumn{5}{|c|}{ Kapsam Geçerlik Ölçütü (KGÖ) } & \multicolumn{5}{|c|}{0.99} \\
\hline \multicolumn{5}{|c|}{ Kapsam Geçerlik İndeksi (KGI) } & \multicolumn{5}{|c|}{1.000} \\
\hline
\end{tabular}

Tablo 6'da KGO, KGÖ ve KGİ değerlerine bakıldığında, tutum ölçeği için KGO değeri KGÖ değerinden büyük 20 maddenin, anket için KGO değeri KGÖ değerinden büyük 10 maddenin kaldığı ve bu maddelerin kapsam geçerliğini sağladığı söylenebilir. Kapsam geçerliğini sağlayan tutumölçeği ve anketin, yapı geçerliğinin de sağlandığını ortaya koymak amacıyla, öncelikle Kaiser-Meyer-Olkin (KMO) ve Barlett Sphericity testine tabi tutulmuştur. Test sonuçları Tablo 7'de görülmektedir.

Tablo 7

Faktör Analizi Uygunluğu KMO ve Barlett Testi Sonuçları

\begin{tabular}{|c|c|c|}
\hline \multicolumn{3}{|c|}{ Tutum Ölçeği } \\
\hline Kaiser-Meyer-Olkin Örnekleme Yeterliği & & .848 \\
\hline & $\chi^{2}$ & 734.832 \\
\hline Bartlett's Sphericity Testi & $\mathrm{Sd}$ & 190 \\
\hline & $\mathrm{p}$ & .000 \\
\hline \multicolumn{3}{|c|}{ Anket } \\
\hline \multicolumn{2}{|c|}{ Kaiser-Meyer-Olkin Örnekleme Yeterliği Ölçümü } & .635 \\
\hline \multirow{3}{*}{ Bartlett's Sphericity Testi } & $\chi^{2}$ & 133.457 \\
\hline & $\mathrm{Sd}$ & 45 \\
\hline & $\mathrm{p}$ & .000 \\
\hline
\end{tabular}

Tablo 7'ye göre, hem tutum ölçeği, hem de anketin KMO değerinin 0.60'dan yüksek çıkması $\left(\mathrm{KMO}_{\text {Tutum }}=0.848\right.$ $\left.>0.60, \mathrm{KMO}_{\text {Anket }}=0.635>0.60\right)$ ve Barlett testi sonucu hesaplanan ki kare değerinin .05 düzeyinde anlaml çıkması (Tutum $\chi_{190}^{2}=734.832, p<.05$, Anket $\chi^{2}{ }_{45}=133.457, p<.05$ ) maddelerin faktörleştirilebilir ve faktör analizine uygun olduğunu göstermektedir. Tablo 8 ve Tablo 9' da tutum ölçeği ve anket için yapılan faktör analizi sonuçları görülmektedir. 
Gökalp Parasız-Elçin Arslan Kaya

Bilim ve Sanat Merkezlerindeki Öğrencilerin Müzik Dersinde Karşılaştıkları Sorunlar ve

Derse Yönelik Tutumlarının İncelenmesi

GSED, 2021; Cilt: 27, Say1: 46: 101-120

https://doi.org/10.32547/ataunigsed.843035

\section{Tablo 8}

Tutum Ölçeği Faktör Analizi Toplam Varyans Açıklaması Tablosu

\begin{tabular}{|c|c|c|c|c|c|c|c|c|c|}
\hline \multirow{2}{*}{ Madde } & \multicolumn{3}{|c|}{ Başlangıç Özdeğerleri } & \multicolumn{3}{|c|}{ Kareli Yüklerin Ağırlıklı Toplamları } & \multicolumn{3}{|c|}{ Kareli Yüklerin DöndürülmüşToplamları } \\
\hline & Toplam & $\%$ Varyans & \% Yiğılmalı & Toplam & $\%$ Varyans & \% Yiğılmalı & Toplam & $\%$ Varyans & \% Yiğılmalı \\
\hline 1 & 10.257 & 51.285 & 51.285 & 7.534 & 37.671 & 37.671 & 7.424 & 37.120 & 37.120 \\
\hline 2 & 2.109 & 10.546 & 61.830 & 3.131 & 15.656 & 53.327 & 2.490 & 12.450 & 49.571 \\
\hline 3 & 1.361 & 6.807 & 68.638 & 1.678 & 8.391 & 61.718 & 2.068 & 10.339 & 59.909 \\
\hline 4 & 1.134 & 5.668 & 74.306 & .813 & 4.066 & 65.784 & 1.175 & 5.875 & 65.784 \\
\hline 5 & .904 & 4.519 & 78.825 & & & & & & \\
\hline 6 & .714 & 3.572 & 82.397 & & & & & & \\
\hline 7 & .562 & 2.808 & 85.204 & & & & & & \\
\hline 8 & .534 & 2.670 & 87.874 & & & & & & \\
\hline 9 & .453 & 2.265 & 90.139 & & & & & & \\
\hline 10 & .384 & 1.919 & 92.058 & & & & & & \\
\hline 11 & .295 & 1.476 & 93.534 & & & & & & \\
\hline 12 & .255 & 1.273 & 94.807 & & & & & & \\
\hline 13 & .225 & 1.123 & 95.930 & & & & & & \\
\hline 14 & .211 & 1.053 & 96.983 & & & & & & \\
\hline 15 & .165 & .826 & 97.809 & & & & & & \\
\hline 16 & .151 & .756 & 98.565 & & & & & & \\
\hline 17 & .123 & .616 & 99.181 & & & & & & \\
\hline 18 & .071 & .353 & 99.534 & & & & & & \\
\hline 19 & .056 & .280 & 99.814 & & & & & & \\
\hline 20 & .037 & .186 & 100.000 & & & & & & \\
\hline
\end{tabular}

Tablo 9

Anket Faktör Analizi Toplam Varyans Açıklaması Tablosu

\begin{tabular}{|c|c|c|c|c|c|c|c|c|c|}
\hline \multirow{2}{*}{ Madde } & \multicolumn{3}{|c|}{ Başlangıç Özdeğerleri } & \multicolumn{3}{|c|}{ Kareli Yüklerin Ağırlıklı Toplamları } & \multicolumn{3}{|c|}{ Kareli Yüklerin DöndürülmüşToplamları } \\
\hline & Toplam & $\%$ Varyans & \% Yiğılmalı & Toplam & $\%$ Varyans & \% Yiğılmalı & Toplam & $\%$ Varyans & \% Yı̆̆glmalı \\
\hline 1 & 3.732 & 37.316 & 37.316 & 1.748 & 17.483 & 17.483 & 1.830 & 18.302 & 18.302 \\
\hline 2 & 1.536 & 15.364 & 52.680 & 2.781 & 27.810 & 45.293 & 1.781 & 17.810 & 36.113 \\
\hline 3 & 1.278 & 12.782 & 65.462 & .759 & 7.586 & 52.878 & 1.677 & 16.766 & 52.878 \\
\hline 4 & .951 & 9.514 & 74.976 & & & & & & \\
\hline 5 & .704 & 7.040 & 82.016 & & & & & & \\
\hline 6 & .474 & 4.742 & 86.758 & & & & & & \\
\hline 7 & .443 & 4.435 & 91.193 & & & & & & \\
\hline 8 & .394 & 3.945 & 95.138 & & & & & & \\
\hline 9 & .320 & 3.197 & 98.334 & & & & & & \\
\hline 10 & .167 & 1.666 & 100.000 & & & & & & \\
\hline
\end{tabular}

Tutum ölçeği ve ankette yer alan maddelerin başlangıç özdeğerlerine bakıldığında, her iki ölçekte de birinci faktör yük değerinin yüksek çıktığ 1 görülmektedir $\left(\mathrm{BÖ}_{\text {Tutum }}=10.257, \mathrm{BÖ}_{\text {Anket }}=3.732\right)$. Yine her iki ölçekte de birinci faktörün tek başına açıkladığı varyansın yüksek olduğu görülmektedir (Varyans ${ }_{T u t u m}=\% 51.285$, Varyans Anket $=$ \%37.316). Bu noktadan hareketle, her iki ölçekte de maddelerin büyük çoğunluğunun tek faktörde birleştiği ve ölçeklerin tek boyutlu bir yapıda olduğu söylenebilir.

Kapsam ve yapı geçerliğini sağlayan tutum ve özyeterlik algısı ölçeklerinin güvenirliğini test etmek üzere Cronbach's Alpha güvenirlik testi uygulanmıştır. Özdamar (2011) alpha katsayısı değerlendirme ölçütünü şu şekilde belirtmiştir:

$0.00<\alpha<0.40$ ise ölçek güvenilir değildir.

$0.40<\alpha<0.60$ ise ölçek düşük güvenirliktedir.

$0.60<\alpha<0.80$ ise oldukça güvenilirdir.

$0.80<\alpha<1.00$ ise ölçek yüksek derecede güvenilir bir ölçektir (s. 522).

Tablo 10’da tutum ölçeği ve ankete ilişkin Cronbach's Alpha güvenirlik testi sonuçları görülmektedir. 


\section{Tablo 10}

Tutum Ölçeği ve Anket Cronbach's Alpha Güvenirlik Testi Sonuçları

\begin{tabular}{|c|c|}
\hline Tutum Maddeleri & Cronbach's Alpha \\
\hline BSM’ müzik alanını kendi isteğim ile tercih ettim. & .583 \\
\hline BSM' müzik alanını ailemin önerisi ile tercih ettim. & .590 \\
\hline BSM’ de gördüğümüz müzik derslerini severim. & .439 \\
\hline BSM’ de gördüğümüz müzik derslerini ilgi çekici bulurum. & .409 \\
\hline BSM’ de gördüğümüz müzik derslerine çalışmaktan skkılırım. & .600 \\
\hline BSM’ de gördüğümüz müzik derslerine istekli bir şekilde çalışırım. & .438 \\
\hline BSM’ de gördüğümüz müzik dersleri ile ilgili konuşmaktan zevk alırım. & .408 \\
\hline BSM’ de gördüğümüz müzik dersleri ile ilgili hiçbir şey duymak istemem. & .599 \\
\hline BSM’ de gördüğümüz müzik dersleri kendime olan güvenimi artırır. & .409 \\
\hline BSM’ de gördüğümüz müzik derslerinin beni sosyalleştireceğini düşünürüm. & .501 \\
\hline BSM’ de gördüğümüz müzik derslerinde öğrendiklerimizi, uygulamaya dökemeyeceğimi düşünürüm. & .605 \\
\hline BSM’ de gördüğümüz müzik derslerine geç kalmak beni rahatsız eder. & .432 \\
\hline BSM’ de gördüğümüz müzik derslerine diğer derslerimden daha çok önem veririm. & .438 \\
\hline BSM’ de gördüğümüz müzik derslerinde öğretilen eserleri söylemekten hoşlanırım. & .417 \\
\hline BSM’ de gördüğümüz müzik derslerinin beni kültürel anlamda geliştirdiğine inanırım. & .416 \\
\hline BSM’ de gördüğümüz müzik dersleriyle ilgili etkinliklere (konser v.b.) severek katılırım. & .412 \\
\hline BSM’ de gördüğümüz müzik derslerinde zamanımın boşa harcandığını düşünürüm. & .596 \\
\hline BSM’ de gördüğümüz müzik derslerine mecbur olduğum için çalışırım. & .591 \\
\hline İleride müzikle ilgili bir meslek alanını tercih etmek isterim. & .476 \\
\hline Müziği ilerleyen yaşamımda hobi olarak devam ettirmek isterim. & .526 \\
\hline Toplam Cronbach’s Alpha & .605 \\
\hline Anket Soruları & Cronbach's Alpha \\
\hline BSM'de gördüğümüz müzik dersi ile okulda gördüğümüz müzik dersinin konuları birbirinden farklıdır. & .960 \\
\hline Burada müzik dersini daha detaylı öğreniyoruz. & .959 \\
\hline BSM'de müzik dersi enstrüman çalmayı öğrenmekle sınırlıdır. & .961 \\
\hline Okulda flüt ya da melodika öğrenirken burada farklı enstrümanların çalınışlarını öğreniyoruz. & .959 \\
\hline BSM' de sınıfımızın fiziki şartları (araç-gereç ve enstrüman) yeterli değil. & .960 \\
\hline BSM' de enstrüman çalmakta ve öğrenmekte güçlük çekiyorum. & .960 \\
\hline BSM' de gördüğümüz konular okulda işlediklerimizle aynı olduğu için sıkılıyorum. & .960 \\
\hline BSM’ de öğretmenimiz derste farklı materyallerden yararlanıyor. & .961 \\
\hline BSM'de öğretmenimiz Türk müzik kültürüne ait eserleden sıkça yararlanıyor. & .961 \\
\hline BSM' de ileri düzeyde müzik eğitimi gördüğümüz için öğrenmekte güçlük çekiyorum. & .960 \\
\hline
\end{tabular}

Sonuç olarak görüldüğü gibi tutum ölçeğinin bütününe ilişkin güvenirlik katsayısı (Cronbach’s Alpha) 0.605 ve anketin bütününe ilişkin güvenirlik katsayısı (Cronbach's Alpha) 0.959 olarak elde edilmiştir. Tutum ölçeği oldukça ve anket ise yüksek derecede güvenilirdir.

\subsection{Süreç/Uygulama}

Bilim ve Sanat Merkezlerindeki müzik dersleri konuları kapsamında öğretmenlerin derslerinde hangi öğretim yöntemlerini kullandıklarını belirlemek üzere, Antalya ilinde bulunan BSM'de görev yapmakta olan 2 müzik öğretmenine ve Alanya ilçesinde görev yapmakta olan 2 müzik öğretmenine, yarı yapılandırılmış görüşme formu uygulanmıştır. Bilim ve Sanat Merkezlerindeki öğrencilere müzik derslerine ilişkin 5'li likert tipi toplam 20 sorudan oluşan 'tutum ölçeği', cinsiyet, sınıf ve yaş değişkenlerine kapsamında hazırlanmış ve uygulanmıştır. Yine bu kurumdaki öğrencilere, müzik derslerinde karşılaştıkları problemlere yönelik hazırlanan 5'li likert tipi ve 10 sorudan oluşan anket uygulanmıştır. Bu üç uygulamadan elde edilen veriler, istatistiksel yöntemle ayrıntılı bir şekilde analiz edilip yorumlanmıştır.

Tüm bu formların uygulanabilmesi için gerekli izin alınmış ve alınan izin belgeleri ile birlikte formlar çoğaltılarak BSM'lerdeki öğretmen ve öğrencilere, araştırmacının kendisi tarafından uygulanmıştır.

\subsection{Verilerin Analizi}

Bilim ve Sanat Merkezlerindeki müzik dersleri konuları kapsamında öğretmenlerin derslerinde hangi öğretim yöntemlerini kullandıklarını belirlemek üzere uzman görüşleri alınarak hazırlanan yarı yapılandırılmış görüşme formundan elde edilen veriler betimsel yöntemle analiz edilmiştir. 
Varyansların eşitliğini test etmek amacıyla yapılan Levene Testi sonuçlarına göre varyanslarda fark olmadığı ve eşit olduğu tespit edilmiştir $\left(\mathrm{p}_{\text {Tutum }}=0.618>0.05\right)$.

Tablo 11

Tutum Ölçeği Varyans Eşitliğine Yönelik Levene Testi Sonuçları

\begin{tabular}{lllll}
\hline Tutum & Levene İstatistiği & sd1 & sd2 & $\mathrm{P}$ \\
\hline Tutum Ortalama & 0.767 & 7 & 39 & .618 \\
\hline
\end{tabular}

Tüm bu bilgiler doğrultusunda ölçekte yer alan boyutların normal dağılıma sahip olmadığı veya gözlem sayısının az olduğu durumlarda tek grup puanlarının (Tutum Puanları) karşılaştırılmasında Wilcoxon İşaretli Sıralar Testi, iki grubun karşılaştırılmasında Mann-Whitney U testi kullanılmıştır. İkiden fazla grubun karşılaştırılmasında ise Kruskal-Wallis H yerine tek faktörlü Varyans analizi kullanılmış ve farklılığın hangi gruplardan kaynaklandığını belirlemek için ise çoklu karşılaştırma testlerinden Bonferroni testi kullanılmıştır.

Burada veriler normal dağılım göstermediği halde iki gruptan fazla grup için tek faktörlü Varyans analizi kullanılmasının sebebi, non-parametrik Kruskal-Wallis H testinde farklılığın hangi gruptan kaynaklandığını belirlemeye yönelik herhangi bir test seçeneğinin bulunmayışıdır. Testlere ilişkin tablolarda Wilcoxon İşaretli Sıralar Testi için N, Sıra ort., Sıra Top., Z ve p değerleri, Mann-Whitney U testi için ise N, Sıra ort., Sıra Top., U ve p değerleri verilirken; tek faktörlü Varyans analizi için Kareler Top., sd, Kareler Ort. F ve p değerleri, Bonferroni Post Hoctesti için ise $\overline{\mathbf{x}}$, Ortalama Farkı, ss ve p değerleri verilmiştir. Çoklu karşılaştırma testlerinde ayrıca tabloların altında farklılığın nereden kaynaklandığı ile ilgili bilgilere de yer verilmiştir. Ayrıca Tutum puanlarının ve anket cevaplarının dağılımları için frekans (f) ve yüzde (\%) değerleri kullanılmıştır.

Çalışmada yer alan analizler için, SPSS 17.0 paket programı kullanılmış ve analizler için elde sonuçlar farklılıklara yönelik olarak 0.05 anlamlılık düzeyinde yorumlanmıştır.

\section{Bulgular}

\subsection{Bilim ve Sanat Merkezlerindeki Müzik Dersleri ve Konuları Kapsamında Öğretim Yöntemlerine İlişkin Bulgular}

Tablo 12

Bilim ve Sanat Merkezlerindeki Müzik Dersleri ve Konuları Kapsamında Öğretim Yöntemleri

\begin{tabular}{|c|c|c|c|c|c|c|c|c|c|c|}
\hline & \multicolumn{5}{|c|}{ Dersler } & \multicolumn{5}{|c|}{ Öğretim Yöntemleri } \\
\hline & Koro & Orkestra & $\begin{array}{c}\text { Bireysel } \\
\text { Çalgı }\end{array}$ & $\begin{array}{l}\text { Sanat } \\
\text { Tarihi }\end{array}$ & $\begin{array}{l}\text { Müzik } \\
\text { Teorisi }\end{array}$ & $\begin{array}{c}\text { Anlatim } \\
\text { Soru/Cevap }\end{array}$ & $\begin{array}{c}\text { Örnekleme } \\
\text { Tartışma }\end{array}$ & $\begin{array}{c}\text { Performans } \\
\text { Uygulama }\end{array}$ & $\begin{array}{c}\text { Ritim } \\
\text { Atölyesi }\end{array}$ & $\begin{array}{c}\text { Toplu } \\
\text { Seslendir } \\
\text { me }\end{array}$ \\
\hline Ö1 & $\sqrt{ }$ & $\sqrt{ }$ & $\sqrt{ }$ & & $\sqrt{ }$ & $\sqrt{ }$ & & $\sqrt{ }$ & $\sqrt{ }$ & \\
\hline Ö2 & & & $\sqrt{ }$ & $\sqrt{ }$ & & $\sqrt{ }$ & $\sqrt{ }$ & $\sqrt{ }$ & & $\sqrt{ }$ \\
\hline Ö3 & $\sqrt{ }$ & $\sqrt{ }$ & $\sqrt{ }$ & & $\sqrt{ }$ & $\sqrt{ }$ & $\sqrt{ }$ & $\sqrt{ }$ & $\sqrt{ }$ & $\sqrt{ }$ \\
\hline Ö4 & $\sqrt{ }$ & $\sqrt{ }$ & $\sqrt{ }$ & & $\sqrt{ }$ & $\sqrt{ }$ & $\sqrt{ }$ & $\sqrt{ }$ & $\sqrt{ }$ & $\sqrt{ }$ \\
\hline
\end{tabular}

Tablo 12'de görüldüğü gibi, Bilim ve Sanat Merkezlerinde eğitimi verilen müzik dersleri; Koro, Orkestra, Bireysel Çalg1, Sanat Tarihi, Müzik Teorisi olup öğretim yöntemlerinin ise; Anlatım/soru-cevap, Örnekleme/Tartışma, Performans/Uygulama, Ritim Atölyesi ve Toplu Seslendirme olduğu öğretmenler tarafından belirtilmiştir.

\subsection{Bilim ve Sanat Merkezlerinde Öğrencilerin Müzik Derslerine Yönelik Tutumlarına İlișkin Bulgular}

Tablo 13

Öğrencilerin BSM Müzik Derslerine Yönelik Tutumlart

\begin{tabular}{|c|c|c|c|c|c|c|c|c|c|c|c|c|c|c|}
\hline \multirow{2}{*}{$\begin{array}{l}\text { Tutum } \\
\text { Maddeleri }\end{array}$} & \multicolumn{2}{|c|}{$\begin{array}{l}\text { Kesinlikle } \\
\text { Katılmıyorum }\end{array}$} & \multicolumn{2}{|c|}{ Katılmiyorum } & \multicolumn{2}{|c|}{ Kararsızım } & \multicolumn{2}{|c|}{ Katıliyorum } & \multicolumn{2}{|c|}{$\begin{array}{l}\text { Kesinlikle } \\
\text { Katıliyorum }\end{array}$} & \multicolumn{2}{|c|}{ Belirtilmeyen } & \multicolumn{2}{|c|}{ Toplam } \\
\hline & $\mathrm{f}$ & $\%$ & $\mathrm{f}$ & $\%$ & $\mathrm{f}$ & $\%$ & $\mathrm{f}$ & $\%$ & $\mathrm{f}$ & $\%$ & $\mathrm{f}$ & $\%$ & $\mathrm{f}$ & $\%$ \\
\hline 1 & 2 & 4.3 & 0 & 0 & 3 & 6.4 & 13 & 27.7 & 29 & 61.7 & 0 & 0 & 47 & 100 \\
\hline 2 & 9 & 19.1 & 17 & 36.2 & 6 & 12.8 & 11 & 23.4 & 4 & 8.5 & 0 & 0 & 47 & 100 \\
\hline 3 & 2 & 4.3 & 0 & 0 & 0 & 0 & 13 & 27.7 & 32 & 68.1 & 0 & 0 & 47 & 100 \\
\hline 4 & 1 & 2.1 & 1 & 2.1 & 3 & 6.4 & 15 & 31.9 & 26 & 55.3 & 1 & 2.1 & 47 & 100 \\
\hline 5 & 23 & 48.9 & 14 & 29.8 & 6 & 12.8 & 3 & 6.4 & 1 & 2.1 & 0 & 0 & 47 & 100 \\
\hline 6 & 1 & 2.1 & 1 & 2.1 & 4 & 8.5 & 21 & 44.7 & 19 & 40.4 & 1 & 2.1 & 47 & 100 \\
\hline 7 & 1 & 2.1 & 2 & 4.3 & 4 & 8.5 & 17 & 36.2 & 23 & 48.9 & 0 & 0 & 47 & 100 \\
\hline 8 & 33 & 70.2 & 11 & 23.4 & 0 & 0 & 1 & 2.1 & 1 & 2.1 & 1 & 2.1 & 47 & 100 \\
\hline 9 & 1 & 2.1 & 3 & 6.4 & 3 & 6.4 & 21 & 44.7 & 19 & 40.4 & 0 & 0 & 47 & 100 \\
\hline 10 & 2 & 4.3 & 2 & 4.3 & 13 & 27.7 & 12 & 25.5 & 18 & 38.3 & 0 & 0 & 47 & 100 \\
\hline 11 & 23 & 48.9 & 12 & 25.5 & 4 & 8.5 & 5 & 10.6 & 3 & 6.4 & 0 & 0 & 47 & 100 \\
\hline 12 & 4 & 8.5 & 8 & 17.0 & 2 & 4.3 & 18 & 38.3 & 15 & 31.9 & 0 & 0 & 47 & 100 \\
\hline 13 & 5 & 10.6 & 10 & 21.3 & 20 & 42.6 & 9 & 19.1 & 3 & 6.4 & 0 & 0 & 47 & 100 \\
\hline 14 & 1 & 2.1 & 1 & 2.1 & 5 & 10.6 & 11 & 23.4 & 29 & 61.7 & 0 & 0 & 47 & 100 \\
\hline 15 & 1 & 2.1 & 1 & 2.1 & 5 & 10.6 & 15 & 31.9 & 25 & 53.2 & 0 & 0 & 47 & 100 \\
\hline
\end{tabular}


Tablo 13'ün devamı

\begin{tabular}{|c|c|c|c|c|c|c|c|c|c|c|c|c|c|c|}
\hline \multirow{2}{*}{$\begin{array}{c}\text { Tutum } \\
\text { Maddeleri }\end{array}$} & \multicolumn{2}{|c|}{$\begin{array}{c}\text { Kesinlikle } \\
\text { Katılmiyorum }\end{array}$} & \multicolumn{2}{|c|}{ Katılmiyorum } & \multicolumn{2}{|c|}{ Kararsızım } & \multicolumn{2}{|c|}{ Kat1liyorum } & \multicolumn{2}{|c|}{$\begin{array}{c}\text { Kesinlikle } \\
\text { Katılıyorum }\end{array}$} & \multicolumn{2}{|c|}{ Belirtilmeyen } & \multicolumn{2}{|c|}{ Toplam } \\
\hline & $\mathrm{f}$ & $\%$ & $\mathrm{f}$ & $\%$ & $\mathrm{f}$ & $\%$ & $\mathrm{f}$ & & $\mathrm{f}$ & $\%$ & $f$ & $\%$ & $\mathrm{f}$ & $\%$ \\
\hline 16 & 2 & 4.3 & 0 & 0 & 3 & 6.4 & 13 & 27.7 & 29 & 61.7 & 0 & 0 & 47 & 100 \\
\hline 17 & 38 & 80.9 & 5 & 10.6 & 1 & 2.1 & 1 & 2.1 & 2 & 4.3 & 0 & 0 & 47 & 100 \\
\hline 18 & 25 & 53.2 & 13 & 27.7 & 3 & 6.4 & 4 & 8.5 & 2 & 44.34 & 0 & 0 & 47 & 100 \\
\hline 19 & 4 & 8.5 & 6 & 12.8 & 18 & 38.3 & 10 & 21.3 & 9 & 19.1 & 0 & 0 & 47 & 100 \\
\hline 20 & 5 & 10.6 & 1 & 2.1 & 9 & 19.1 & 13 & 27.7 & 19 & 40.4 & 0 & 0 & 47 & 100 \\
\hline
\end{tabular}

Tablo 13. incelendiğinde 47 öğrenciden; 42 öğrencinin \%89.4 oranla BSM müzik alanını kendi istekleri ile tercih ettikleri (madde 1), 3 ögrencinin \%6.4 oranla bu konuda kararsız olduğu, 2 öğrencinin ise \%4.3 oranla BSM müzik alanını istemeyerek tercih ettikleri;

26 öğrencinin \%55.3 oranla BSM müzik alanını aile önerisi ile değil kendi istekleri tercih ettikleri (madde 2), 6 öğrencinin \%12.8 oranla bu konuda kararsız olduğu, 15 öğrencinin ise \%28.9 oranla BSM müzik alanını aile önerisi tercih ettikleri;

45 öğrencinin \%95.8 oranla BSM'de gördükleri müzik dersini sevdikleri (madde 3), 2 öğrencinin ise \%4.3 oranla müzik dersini sevmedikleri;

41 öğrencinin \%87.2 oranla BSM'deki müzik derslerini ilgi çekici buldukları (madde 4), 3 öğrencinin \%6.4 oranla bu konuda kararsız olduğu, 2 öğrencinin ise \%4.2 oranla müzik derslerini ilgi çekici bulmadığı;

37 öğrencinin \%78.7 oranla BSM'deki müzik derslerine çalışmaktan hoşlandıkları (madde 5), 6 öğrencinin \%12.8 oranla bu konuda kararsız olduğu, 4 öğrencinin ise \%8.5 oranla müzik derslerine çalışmayı sıkıcı buldukları;

40 öğrencinin \%85.1 oranla BSM'deki müzik derslerine zevkle çalıştı̆̆ 1 (madde 6), 4 öğrencinin \%8.5 oranla bu konuda kararsız olduğu, 2 öğrencinin ise $\% 4.2$ oranla müzik derslerine çalışmakta istekli olmadığı;

40 öğrencinin \%85.1 oranla BSM'deki müzik dersleri ile ilgili konuşmaktan zevk aldığı (madde 7), 4 öğrencinin $\% 8.5$ oranla bu konuda kararsız olduğu, 3 öğrencinin ise \%6.4 oranla müzik dersleri ile ilgili konuşmaktan zevk almadığ1;

2 öğrencinin \%4.2 oranla BSM'deki müzik dersleri ile ilgili hiçbir şey duymak istemediği (madde 8), 44 öğrencinin ise $\% 93.6$ oranla bu görüşe katılmadıkları;

40 öğrencinin \%85.1 oranla BSM'deki müzik derslerinin bireyin kendine olan güvenini artırdığını düşündükleri (madde 9), 3 öğrencinin \%6.4 oranla bu konuda kararsız olduğu, 4 öğrencinin ise \%8.5 oranla bu görüşe katılmadıkları;

30 öğrencinin \%63,8 oranla BSM'deki müzik derslerinin bireyi sosyalleştireceğini düşündükleri (madde 10), 13 öğrencinin $\% 27.7$ oranla bu konuda kararsız olduğu, 4 öğrencinin ise $\% 8.5$ oranla müzik derslerinin sosyalleşmede etkili olmadığını düşündükleri;

35 öğrencinin \%74.4 oranla BSM'deki müzik derslerinde öğrendiklerini uygulamada da kullanabileceklerini düşündükleri (madde 11), 4 öğrencinin \%8.5 oranla bu konuda kararsız olduğu, 8 öğrencinin ise \%17.0 oranla öğrendiklerini uygulamalı olarak kullanamayacağını düşündükleri;

33 öğrencinin \%70.2 oranla BSM'deki müzik derslerine geç kalma konusunda kendilerini rahatsız hissettikleri (madde 12), 2 öğrencinin \%4.3 oranla bu konuda kararsız olduğu, 12 öğrencinin ise $\% 25.5$ oranla müzik derslerine geç kalmayı sorun etmedikleri;

20 öğrencinin \%42.6 oranla BSM'deki müzik derslerine diğer derslerden daha çok önem verme konusunda kararsız kaldığı (madde 13), 15 öğrencinin \%31.9 oranla müzik derslerine diğer derslerden daha çok önem vermediği, 12 öğrencinin ise $\% 25.5$ oranla müzik derslerine diğer derslerden daha çok önem verdiği;

40 öğrencinin \%85.1 oranla BSM'deki müzik derslerinde öğretilen eserleri söylemekten hoşlandığı (madde 14), 5 öğrencinin \%10.6 oranla bu konuda kararsız olduğu, 2 öğrencinin ise $\% 4.2$ oranla müzik derslerinde öğretilen eserleri söylemekten hoşlanmadığı;

40 öğrencinin \%85.1 oranla BSM'deki müzik derslerinin kendilerini kültürel anlamda geliştirdiğini düşündükleri (madde 15), 5 öğrencinin \% 10.6 oranla bu konuda kararsız olduğu, 2 öğrencinin ise \% 4.2 oranla müzik derslerinin kendilerini kültürel anlamda geliştirmediğini düşündükleri;

42 öğrencinin \%89.4 oranla BSM'deki müzik dersleri ile ilgili etkinliklere severek katıldıkları (madde 16), 3 öğrencinin \%6.4 oranla bu konuda kararsız olduğu, 2 öğrencinin ise \%4.3 oranla müzik dersleri ile ilgili etkinliklere katılmayı sevmedikleri; 
43 öğrencinin \%91.5 oranla BSM’deki zamanlarının boşa harcandığını düşünmedikleri (madde 17), 1 öğrencinin $\% 2.1$ oranla bu konuda kararsız olduğu, 3 öğrencinin ise \%6.4 oranla müzik derslerinin zamanı boşa harcadığını düşündükleri;

38 öğrencinin \%80.9 oranla BSM'deki müzik derslerine mecbur olduğu için değil istediği için çalıştığ1 (madde 18), 3 öğrencinin \%6.4 oranla bu konuda kararsız olduğu, 6 öğrencinin ise \%12.8 oranla müzik derslerine mecburiyet hissettiği için çalıştığı;

19 öğrencinin \%40.4 oranla ileride müzik ile ilgili bir meslek alanını seçmek istediği (madde 19), 18 öğrencinin \%38.3 oranla bu konuda kararsız olduğu, 10 öğrencinin ise \%21.3 oranla müziği meslek olarak seçmek istemediği;

32 öğrencinin \%68.1 oranla ileriki yaşamında müziği hobi olarak devam ettirmek istediği (madde 20), 9 öğrencinin \%19.1 oranla bu konuda kararsız olduğu, 6 öğrencinin ise \%12.7 oranla müziği meslek olarak devam ettirmek istediği görülmektedir.

Bu bilgiler ışığında, öğrencilerin büyük çoğunluğunun BSM müzik alanını kendi istekleriyle tercih ettikleri, ailenin önerisi ile tercih eden öğrenci sayısının az olduğu, buna bağlı olarak BSM'de görülen müzik dersine karşı tutumların büyük ölçüde olumlu olduğu ve olumsuz tutum sergileyen öğrencilerin ise müzik alanını aile isteği ile seçenler olduğu söylenebilir.

\subsection{Bilim ve Sanat Merkezlerinde Öğrencilerin Müzik Derslerinde Karşılaştıkları Problemlere İlişkin Bulgular}

Tablo 14

BSM ve Okuldaki Müzik Dersi Konularının Farklılık Durumu

\begin{tabular}{lcc}
\hline Seçenekler & Frekans (f) & Yüzde (\%) \\
\hline Kesinlikle Katılmiyorum & 2 & 4.3 \\
Katılmiyorum & 4 & 8.5 \\
Kararsizım & 3 & 6.4 \\
Katıliyorum & 8 & 17.0 \\
Kesinlikle Katıliyorum & 28 & 59.6 \\
Belirtilmeyen & 2 & 4.3 \\
Toplam & 47 & 100.0 \\
\hline
\end{tabular}

Tablo 14'de görüldüğü gibi "BSM'de gördüğümüz müzik dersi ile okulda gördüğümüz müzik dersinin konular1 birbirinden farklıdır." maddesine bağlı olarak öğrenciler \%59.6 oranla Kesinlikle Katılıyorum, \%17.0 oranla Katıliyorum, \%8,5 oranla Katılmiyorum, \%6.4 oranla Kararsızım ve \%4.3 oranla Kesinlikle Katılmiyorum şeklinde görüşlerini belirtmişlerdir. Tablo 14'e bakıldığında yoğunluğun Kesinlikle Katılıyorum ve Katılıyorum seçeneklerinde olduğu ve bunun da BSM'de ve okulda müzik dersinde işlenen konuların birbirinden farklılık gösterdiği anlamına geldiği söylenebilir.

Tablo 15

BSM'de Müzik Dersini Daha Detaylı Görme Durumu

\begin{tabular}{lcc}
\hline Seçenekler & Frekans (f) & Yüzde (\%) \\
\hline Kesinlikle Katılmiyorum & 2 & 4.3 \\
Katılmıyorum & 1 & 2.1 \\
Kararsızım & 1 & 2.1 \\
Katıliyorum & 12 & 25.5 \\
Kesinlikle Katıliyorum & 29 & 61.7 \\
Belirtilmeyen & 2 & 4.3 \\
Toplam & 47 & 100.0 \\
\hline
\end{tabular}

Tablo 15'de görüldüğü gibi “BSM'de müzik dersini daha detaylı öğreniyoruz.” maddesine bağlı olarak öğrenciler, \%61.7 oranla Kesinlikle Katılıorum, \%25.5 oranla Katılıyorum, \%4.3 oranla Kesinlikle Katılmıorum, \%2.1 oranla Kararsızım ve \%2.1 oranla Katılmıyorum şeklinde görüşlerini belirtmişlerdir. Tablo 15'e bakıldığında yoğunluğun Kesinlikle Katılıyorum ve Katılıyorum seçeneklerinde olduğu ve bunun da BSM'de müzik dersinin daha detaylı öğrenildiği anlamına geldiği söylenebilir. 
Gökalp Parasız-Elçin Arslan Kaya

Bilim ve Sanat Merkezlerindeki Öğrencilerin Müzik Dersinde Karșılaștıkları Sorunlar ve

Derse Yönelik Tutumlarının İncelenmesi

GSED, 2021; Cilt: 27, Sayı: 46: 101-120

https://doi.org/10.32547/ataunigsed.843035

\section{Tablo 16}

BSM’de Müzik Dersinin Enstrüman Ağırlıklı Durumu

$\begin{array}{lcc}\text { Seçenekler } & \text { Frekans (f) } & \text { Yüzde (\%) } \\ \text { Kesinlikle Katılmıorum } & 23 & 48.8 \\ \text { Katılmiyorum } & 17 & 36.2 \\ \text { Kararsizım } & 2 & 4.3 \\ \text { Katıliyorum } & 1 & 2.1 \\ \text { Kesinlikle Katıliyorum } & 2 & 4.3 \\ \text { Belirtilmeyen } & 2 & 4.3 \\ \text { Toplam } & 47 & 100.0\end{array}$

Tablo 16'da görüldüğü gibi “BSM'de müzik dersi enstrüman çalmayı öğrenmekle sınırlıdır.” maddesine bağlı olarak öğrenciler, \%48.8 oranla Kesinlikle Katılmıyorum, \%36.2 oranla Katılmıyorum, \%4.3 oranla Kesinlikle Katılıyorum, \%4.3 oranla Kararsızım ve \%2.1 oranla Katılıyorum şeklinde görüşlerini belirtmişlerdir. Tablo 16 'ya bakıldığında yoğunluğun Kesinlikle Katılmıyorum ve Katılmıyorum seçeneklerinde olduğu ve bunun da BSM'de müzik dersinin sadece enstrüman ağırlıklı değil, müzikle diğer konuların da ağırlığının olacağı şekilde yürütüldüğü anlamına geldiği söylenebilir.

Tablo 17

BSM'de Farklı Enstrümanların Ĕ̈itimini Alma Durumu

\begin{tabular}{lcc}
\hline Seçenekler & Frekans (f) & Yüzde (\%) \\
\hline Kesinlikle Katılmiyorum & 4 & 8.5 \\
Katılmıyorum & 2 & 4.3 \\
Kararsizım & 5 & 10.6 \\
Katıliyorum & 12 & 25.5 \\
Kesinlikle Katıliyorum & 22 & 46.8 \\
Belirtilmeyen & 2 & 4.3 \\
Toplam & 47 & 100.0 \\
\hline
\end{tabular}

Tablo 17'de görüldüğü gibi “Okulda flüt ya da melodika öğrenirken BSM'de farklı enstrümanların çalınışlarını öğreniyoruz." maddesine bağlı olarak öğrenciler, \%46.8 oranla Kesinlikle Katılıyorum, \%25.5 oranla Katılıyorum, \%10,6 oranla Kararsızım, \%8.5 oranla Kesinlikle Katılmıyorum ve \%4.3 oranla Katılmıyorum şeklinde görüșlerini belirtmişlerdir. Tablo 17'ye bakıldığında yoğunluğun Kesinlikle Katılıyorum ve Katılıyorum seçeneklerinde olduğu ve bunun da Milli Eğitim'e bağlı diğer okullarda sadece flüt ve melodika öğretilirken, BSM'de bunların dışında da enstrümanların olduğu ve eğitiminin verildiği anlamına geldiği söylenebilir.

Tablo 18

BSM'deki Sinıfların Fiziki Şartlarının Yeterlik Durumu

\begin{tabular}{lcc}
\hline Seçenekler & Frekans (f) & Yüzde (\%) \\
Kesinlikle Katılmiyorum & 17 & 36.2 \\
Katılmiyorum & 16 & 34.0 \\
Kararsizım & 4 & 8.5 \\
Katıliyorum & 2 & 4.3 \\
Kesinlikle Katıliyorum & 4 & 8.5 \\
Belirtilmeyen & 4 & 8.5 \\
Toplam & 47 & 100.0 \\
\hline
\end{tabular}

Tablo 18'de görüldüğü gibi “BSM' de sınıfımızın fiziki şartları (araç-gereç ve enstrüman) yeterli değil." maddesine bağlı olarak öğrenciler, \%36.2 oranla Kesinlikle Katılmıyorum, \%34.0 oranla Katılmıyorum, \%8.5 oranla Kararsızım, \%8.5 oranla Kesinlikle Katılıyorum ve \%4.3 oranla Katılıyorum şeklinde görüşlerini belirtmişlerdir. Tablo 18'e bakıldığında yoğunluğun Kesinlikle Katılmıyorum ve Katılmıyorum seçeneklerinde olduğu ve bunun da BSM'deki sınıfların fiziki şartlarının yeterli olduğu anlamına geldiği söylenebilir. 


\section{Tablo 19}

BSM’de Enstrüman Çalma ve Öğrenmede Güçlük Çekme Durumu

$\begin{array}{lcc}\text { Seçenekler } & \text { Frekans (f) } & \text { Yüzde (\%) } \\ \text { Kesinlikle Katılmıorum } & 22 & 46.8 \\ \text { Katılmiyorum } & 15 & 31.9 \\ \text { Kararsizım } & 3 & 6.4 \\ \text { Katıliyorum } & 3 & 6.4 \\ \text { Kesinlikle Katıliyorum } & 1 & 2.1 \\ \text { Belirtilmeyen } & 3 & 6.4 \\ \text { Toplam } & 47 & 100.0\end{array}$

Tablo 19'da görüldüğü gibi “BSM' de enstrüman çalmakta ve öğrenmekte güçlük çekiyorum.” maddesine bağl1 olarak öğrenciler, \%46.8 oranla Kesinlikle Katılmıyorum, \%31.9 oranla Katılmıyorum, \%6.4 oranla Kararsızım, \%6.4 oranla Katılıyorum ve \%2.1 oranla Kesinlikle Katılıyorum şeklinde görüşlerini belirtmişlerdir. Tablo 19'a bakıldığında yoğunluğun Kesinlikle Katılmıyorum ve Katılmıyorum seçeneklerinde olduğu ve bunun da öğrencilerin BSM'de enstrüman çalma ve öğrenmede herhangi bir güçlük çekmediği anlamına geldiği söylenebilir.

Tablo 20

BSM’deki Konuların Okuldaki Konularla Aynı Olma Durumu

\begin{tabular}{lcc}
\hline Seçenekler & Frekans (f) & Yüzde (\%) \\
\hline Kesinlikle Katılmiyorum & 25 & 53.1 \\
Katılmiyorum & 14 & 29.8 \\
Kararsizım & 2 & 4.3 \\
Katıliyorum & 3 & 6.4 \\
Kesinlikle Katıliyorum & 1 & 2.1 \\
Belirtilmeyen & 2 & 4.3 \\
Toplam & 47 & 100.0 \\
\hline
\end{tabular}

Tablo 20'de görüldüğü gibi “BSM' de gördüğümüz konular okulda ișlediklerimizle aynı olduğu için sıkılıyorum." maddesine bağlı olarak öğrenciler, \%53.1 oranla Kesinlikle Katılmıyorum, \%29.8 oranla Katılmıorum, \%6.4 oranla Katılıyorum, \%4.3 oranla Kararsızım ve \%2.1 oranla Kesinlikle Katıliyorum şeklinde görüşlerini belirtmişlerdir. Tablo 20’ye bakıldığında yoğunluğun Kesinlikle Katılmıyorum ve Katılmıyorum seçeneklerinde olduğu ve bunun da BSM'de müzik derslerinde işlenen konuların okulda işlenen konulardan farklı ve ilgi çekici olduğu, bu nedenle de öğrencilerin derslerde sıkılmadıkları anlamına geldiği söylenebilir.

Tablo 21

BSM'deki Müzik Öğretmeninin Farklı Materyallerden Faydalanma Durumu

\begin{tabular}{lcc}
\hline Seçenekler & Frekans (f) & Yüzde (\%) \\
Kesinlikle Katılmiyorum & 1 & 2.1 \\
Katılmiyorum & 5 & 10.6 \\
Kararsizım & 7 & 14.9 \\
Katıliyorum & 17 & 36.2 \\
Kesinlikle Katıliyorum & 14 & 29.8 \\
Belirtilmeyen & 3 & 6.4 \\
Toplam & 47 & 100.0 \\
\hline
\end{tabular}

Tablo 21 'de görüldüğü gibi 'BSM' de öğretmenimiz derste farklı materyallerden yararlanıor.” maddesine bağlı olarak öğrenciler, \%36.2 oranla Katılıyorum, \%29.8 oranla Kesinlikle Katılıyorum, \%14.9 oranla Kararsızım, $\% 10.6$ oranla Katılmıyorum ve $\% 2.1$ oranla Kesinlikle Katılmıyorum şeklinde görüşlerini belirtmişlerdir. Tablo 21 'e bakıldığında yoğunluğun Kesinlikle Katılıyorum ve Katılıyorum seçeneklerinde olduğu ve bunun da BSM'de müzik öğretmeninin ders işlenişinde farklı materyallerden yararlandığı anlamına geldiği söylenebilir. 


\section{Tablo 22}

BSM’deki Müzik Öğretmeninin Türk Müzik Kültürüne Ait Eserlerden Faydalanma Durumu

$\begin{array}{lcc}\text { Seçenekler } & \text { Frekans (f) } & \text { Yüzde (\%) } \\ \text { Kesinlikle Katılmiyorum } & 1 & 2.1 \\ \text { Katılmiyorum } & 2 & 4.3 \\ \text { Kararsızım } & 15 & 31.9 \\ \text { Katıliyorum } & 16 & 34.0 \\ \text { Kesinlikle Katıliyorum } & 11 & 23.4 \\ \text { Belirtilmeyen } & 2 & 4.3 \\ \text { Toplam } & 47 & 100.0\end{array}$

Tablo 22'de görüldüğü gibi "BSM'de öğretmenimiz Türk müzik kültürüne ait eserlerden sıkça yararlanıyor." maddesine bağlı olarak öğrenciler, \%34.0 oranla Katılıyorum, \%31.9 oranla Kararsızım, \%23.4 oranla Kesinlikle Katılıyorum, \%4.3 oranla Katılmıyorum ve \%2.1 oranla Kesinlikle Katılmıyorum şeklinde görüşlerini belirtmişlerdir. Tablo 22'ye bakıldığında yoğunluğun Katılıyorum, Kararsızım ve Kesinlikle Katılıyorum seçeneklerinde olduğu ve bunun da BSM'de müzik öğretmeninin ders işlenişinde Türk müzik kültürüne ait eserlerden yeterince yararlandığı anlamına geldiği söylenebilir.

Tablo 23

BSM'de İleri Düzey Müzik Eğitiminden Dolayı Öğrenme Güçlüğü Çekme Durumu

\begin{tabular}{lcc}
\hline Seçenekler & Frekans (f) & Yüzde (\%) \\
\hline Kesinlikle Katılmiyorum & 22 & 46.8 \\
Katılmiyorum & 15 & 31.9 \\
Kararsızım & 3 & 6.4 \\
Katıliyorum & 1 & 2.1 \\
Kesinlikle Katıliyorum & 2 & 4.3 \\
Belirtilmeyen & 4 & 8.5 \\
Toplam & 47 & 100.0 \\
\hline
\end{tabular}

Tablo 23'de görüldüğü gibi “BSM' de ileri düzeyde müzik eğitimi gördüğümüz için öğrenmekte güçlük çekiyorum." maddesine bağlı olarak öğrenciler, \%46.8 oranla Kesinlikle Katılmıyorum, \%31.9 oranla Katılmıyorum, \%6.4 oranla Kararsızım, \%4.3 oranla Kesinlikle Katılıyorum ve \%2.1 oranla Katılıyorum şeklinde görüşlerini belirtmişlerdir. Tablo 23'e bakıldığında yoğunluğun Kesinlikle Katılmıyorum ve Katılmıyorum seçeneklerinde olduğu ve bunun da BSM'de çok ileri düzey bir müzik eğitimi verilmediği ve bundan dolayı öğrencilerin öğrenmede güçlük çekmedikleri anlamına geldiği söylenebilir.

\subsection{Bilim ve Sanat Merkezlerindeki Öğrencilerin Cinsiyet Değişkenine Göre Tutumları Arası Farklıı̆ğa İlişsin Bulgular}

Tablo 24

Cinsiyete Göre BSM Müzik Derslerine Yönelik Tutumlar

\begin{tabular}{lccc}
\hline Cinsiyet & $\mathrm{n}$ & $\%$ & Tutum Ortalama \\
\hline Erkek & 17 & 34.8 & 3.33 \\
Kiz & 30 & 65.2 & 3.41 \\
Toplam & 47 & 100.0 & \\
\hline
\end{tabular}

Tablo 24'de tutum ölçeği maddelerinin ortalama puanları incelendiğinde, Erkeklerin Tutum Ortalama puanının 3.33 olduğu; Kızların Tutum Ortalama puanının 3.41 olduğu görülmektedir. Bu bilgiler doğrultusunda, öğrencilerin genelinin BSM müzik derslerine yönelik tutumlarının yüksek düzeyde olduğu söylenebilir.

30 kişiden oluşan Kız ve 17 kişiden oluşan Erkek gruplarının tutum farklılıklarına bakıldığında sadece "BSM' de gördüğümüz müzik derslerinin beni kültürel anlamda geliştirdiğine inanırım” (madde 15) [U=162.500, $p<0.05]$ maddesinde istatistiksel açıdan anlamlı bir fark olduğu diğer tutum maddelerinde anlamlı bir fark bulunmadığ görülmektedir. Sıra numaraları ortalamaları ve sıra numaraları toplamları incelendiğinde, 'BSM' de gördüğümüz müzik derslerinin beni kültürel anlamda geliştirdiğine inanırım" (madde 15) maddesinde Erkek bireylerin tutum puanlarının siralama puanları ortalamasının $\mathrm{SO}=18.66$ ve siralama puanları toplamının $\mathrm{ST}=298.50 \mathrm{ve} \mathrm{k} 1 \mathrm{z}$ bireylerin sıralama puanları ortalamasının $\mathrm{SO}=26.08$ ve siralama puanları toplamının $\mathrm{ST}=782.50$ olduğu görülmektedir. Bunun anlamının kız bireylerin SO ve ST değerlerinin erkek bireylerden yüksek olduğu, bunun da kız bireylerin tutumlarının BSM' de gördüğümüz müzik derslerinin beni kültürel anlamda geliștirdiğine inanırım" maddesi için erkek bireylere göre daha yüksek olduğu anlamına geldiği söylenebilir. Başka bir anlatımla, kız 
öğrencilerin, müzik derslerinin bireyi kültürel anlamda geliştirdiğine olan yaklaşımları erkek öğrencilere göre daha olumludur. Erkek öğrenciler müzik derslerinin kültürel anlamda gelişim sağladığına kız öğrencilerden daha az inanmaktadir.

Cinsiyet değişkenine göre öğrencilerin tutum ortalama puanlarının farklılı̆̆ına yönelik olarak yapılan MannWhitney U testi sonuçları Tablo 25'de gösterilmiştir.

Tablo 25

Cinsiyete Göre BSM Müzik Dersleri Tutum Ortalama Puanı Farklılıklarına Yönelik Mann-Whitney U Testi Sonuçları

\begin{tabular}{cccccc}
\hline Tutum & Cinsiyet & $\mathrm{N}$ & Sira Ort. & Sira Top. & $\mathrm{U}$ \\
\hline \multirow{3}{*}{ Tutum Ortalama } & Kiz & 30 & 24.97 & 749.00 & 226.000 \\
& Erkek & 17 & 22.29 & 379.00 & .520 \\
& Toplam & 47 & & & \\
\hline
\end{tabular}

Tablo 25'de, 30 kişiden oluşan Kız ve 17 kişiden oluşan Erkek gruplarının tutum ortalama puanları bazında tutum farklılıklarına bakıldığında Tutum Ortalama $[\mathrm{U}=226.000, \mathrm{p}>.05]$ puanları arasında istatistiksel açıdan anlamlı bir fark olmadığı görülmektedir. Sıra numaraları ortalamaları ve sıra numaraları toplamları incelendiğinde, Kızların Tutum Ortalama puanlarının siralama puanları ortalamasının SO $=24.97$ ve siralama puanları toplamının ST $=$ 749.00 ve Erkeklerin Tutum Ortalama puanlarının sıralama puanları ortalamasının $\mathrm{SO}=22.29$ ve sıralama puanları toplamının ST = 379.00 olduğu görülmektedir. Bunun anlamının erkek ve kız bireylerin SO ve ST değerlerinin birbirine çok yakın olduğu, bunun da erkek ve kız bireylerin tutumlarının genel anlamda farklılık göstermediği anlamına geldiği söylenebilir. Başka bir anlatımla tek tek madde bazında tutumlar sadece bir maddede cinsiyet faktörüne göre farklılık gösterse de, tutum ölçeğindeki maddelerin geneli açısından BSM'deki müzik derslerine karşı tutumların cinsiyete göre değişmediği söylenebilir.

\subsection{Bilim ve Sanat Merkezlerindeki Öğrencilerin Sınıf Değişkenine Göre Tutumları Arası Farklılığa İlişkin Bulgular}

Tablo 26

Sınıf Düzeyine Göre BSM Müzik Derslerine Yönelik Tutumlar

\begin{tabular}{|c|c|c|c|}
\hline Sinif & $\mathrm{N}$ & $\%$ & BSM Müzik Dersi Tutum Ortalama \\
\hline 2 & 2 & 4.3 & 3.90 \\
\hline 3 & 5 & 10.6 & 3.50 \\
\hline 4 & 7 & 14.9 & 3.31 \\
\hline 5 & 10 & 21.3 & 3.22 \\
\hline 6 & 7 & 14.9 & 3.19 \\
\hline 7 & 5 & 10.6 & 3.43 \\
\hline 8 & 5 & 10.6 & 3.54 \\
\hline 9 & 6 & 12.8 & 3.60 \\
\hline Toplam & 47 & 100.0 & \\
\hline
\end{tabular}

Tablo 26' da tutum ölçeği maddelerinin ortalama puanları incelendiğinde, Tutum Ortalama puanlarının 2. sınıflarda 3.90, 3. siniflarda 3.50, 4. siniflarda 3.31, 5. Sinıflarda 3.22, 6. siniflarda 3.19, 7. siniflarda 3.43, 8. siniflarda 3.54 ve 9. sinıflarda 3.60 olduğu görülmektedir.

Bu bilgiler doğrultusunda, öğrencilerin genelinin müzik derslerine yönelik tutumlarının yüksek düzeyde olduğu, ancak sıralama yapıldığında en yüksek tutumun 2. sınıflarda olduğu söylenebilir.

Sınıf değişkenine göre öğrencilerin tutum ortalama puanlarının farklılığına yönelik olarak yapılan tek faktörlü Varyans analizi sonuçları Tablo 27'de gösterilmiştir.

Tablo 27

Sınıf Düzeyine Göre BSM Müzik Dersleri Tutum Ortalama Puan Farklılıklarına Yönelik Tek Faktörlü Varyans Analizi Sonuçları

\begin{tabular}{ccccccc}
\hline Tutum & Kaynak (Sınıf) & Kareler Toplamı & sd & Ortalama Kare & F & .226 \\
Tutum Ortalama & Gruplararası & 1.581 & 7 & .081 & 2.791 \\
& Gruplariçi & 3.156 & 39 & $.019^{*}$ & \\
\hline
\end{tabular}

Tablo 27 incelendiğinde farklı sınıflardan öğrencilerin müzik derslerine yönelik tutum puanları arasındaki fark1 belirlemek için tutum maddeleri ortalama puanları bazında yapılan varyans analizi sonucunda tutum ortalama puanları arasında $\left(\mathrm{F}_{7-39}=2.791, \mathrm{p}<.05\right)$ istatistiksel olarak anlamlı bir farklılık bulunmuştur. Bu farklılığın hangi 
sınıflar arasında olduğunu bir başka deyişle farklılığın hangi gruplardan kaynaklandığını belirlemek amacıyla yapılan Bonferroni çoklu karşılaştırma testi sonucunda farklılık gösteren sınıflar Tablo 28'de gösterilmiştir.

Tablo 28

Sinıf Düzeyine Göre BSM Müzik Dersleri Tutum Ortalama Puan Farklllıklarına Yönelik Bonferroni Çoklu Karşılaştırma Testi Sonuçları

\begin{tabular}{|c|c|c|c|c|c|c|c|}
\hline Tutum & Sinıf (a) & $\overline{\mathrm{x}}$ & Sinıf (b) & $\overline{\mathrm{x}}$ & Ortalama Farkı (a-b) & Ss & $\mathrm{p}$ \\
\hline \multirow{7}{*}{ Tutum Ortalama } & \multirow{7}{*}{ 2. Sinif } & \multirow{7}{*}{3.90} & 3. Sinif & 3.50 & .40000 & .23799 & .101 \\
\hline & & & 4. Sinif & 3.31 & .58571 & .22807 & $.014^{*}$ \\
\hline & & & 5. Sinif & 3.22 & .67842 & .22034 & $.004^{*}$ \\
\hline & & & 6. Sinif & 3.18 & .71429 & .22807 & $.003^{*}$ \\
\hline & & & 7. Sinıf & 3.42 & .47111 & .23799 & .055 \\
\hline & & & 8. Sinıf & 3.54 & .36000 & .23799 & .138 \\
\hline & & & 9. Sinif & 3.60 & .30000 & .23226 & .204 \\
\hline
\end{tabular}

Tablo 28 incelendiğinde, yapılan Bonferroni çoklu karşılaştırma testi sonucunda, farklılığın 2. sınıflardan

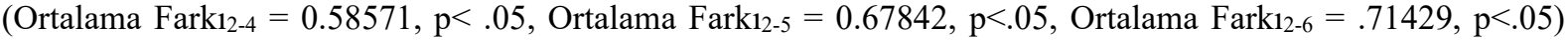
kaynaklandığ bulunmuştur.

Bu sonuçlara göre 2. sınıfların BSM'deki müzik derslerine karşı tutumlarının özellikle 4., 5. ve 6. sınıflar başta olmak üzere diğer sınıflara göre daha yüksek olduğu, tutumları en düşük sınıfların ise 5. ve 6. sınıflar olduğu söylenebilir.

\subsection{Bilim ve Sanat Merkezlerindeki Öğrencilerin Yaş Değişkenine Göre Tutumları Arası Farklılığa İlişkin Bulgular}

Tablo 29

Yaş Düzeyine Göre BSM Müzik Derslerine Yönelik Tutumlar

\begin{tabular}{cccc}
\hline Yaş & $\mathrm{n}$ & $\%$ & BSM Müzik Dersi Tutum Ortalama \\
\hline 8 & 2 & 4.3 & 3.85 \\
9 & 7 & 14.9 & 3.34 \\
10 & 5 & 10.6 & 3.37 \\
11 & 11 & 23.4 & 3.16 \\
12 & 7 & 14.9 & 3.40 \\
13 & 4 & 8.5 & 3.43 \\
14 & 5 & 10.6 & 3.41 \\
15 & 4 & 8.5 & 3.68 \\
16 & 2 & 4.3 & 3.78 \\
\hline Toplam & 47 & 100.0 & \\
\hline
\end{tabular}

Tablo 29'da tutum ölçeği maddelerinin ortalama puanları incelendiğinde, Tutum Ortalama puanlarının 8 yaş grubunda 3.85, 9 yaş grubunda 3.34, 10 yaş grubunda 3.37, 11 yaş grubunda 3.16, 12 yaş grubunda $3.40,13$ yaş grubunda $3.43,14$ yaş grubunda $3.41,15$ yaş grubunda 3.68 ve 16 yaş grubunda 3.78 olduğu görülmektedir.

$\mathrm{Bu}$ bilgiler doğrultusunda, öğrencilerin genelinin müzik derslerine yönelik tutumlarının yüksek düzeyde olduğu, ancak sıralama yapıldığginda en yüksek tutumun 2. sınıflarda olduğu söylenebilir.

Yaş değişkenine göre öğrencilerin tutum ortalama puanlarının farklılığına yönelik olarak yapılan tek faktörlü Varyans analizi sonuçları Tablo 30’da gösterilmiştir.

Tablo 30

Yaş Düzeyine Göre BSM Müzik Dersleri Tutum Ortalama Puan Farklllıklarına Yönelik Tek Faktörlü Varyans Analizi Sonuçlart

\begin{tabular}{rlccccc}
\hline Tutum & Kaynak (Sınıf) & Kareler Toplamı & Sd & Ortalama Kare & $\mathrm{F}$ & $\mathrm{p}$ \\
\hline \multirow{3}{*}{ Tutum Ortalama } & Gruplararası & 1.672 & 8 & .209 & \\
& Gruplariçi & 3.065 & 38 & .081 & 2.591 \\
& Toplam & 4.737 & 46 & & & \\
& & & & & \\
\end{tabular}

Tablo 30. incelendiğinde farklı yaş gruplarından öğrencilerin müzik derslerine yönelik tutum puanları arasındaki farkı belirlemek için tutum maddeleri ortalama puanları bazında yapılan varyans analizi sonucunda tutum ortalama puanları arasında $\left(\mathrm{F}_{8-38}=2.59, \mathrm{p}<.05\right)$ istatistiksel olarak anlamlı bir farklılık bulunmuştur. Bu farklılığın hangi yaş gruplarından kaynaklandığını belirlemek amacıyla yapılan Bonferroni çoklu karşılaştırma testi sonucunda farklılık gösteren yaş grupları Tablo 31 'de gösterilmiştir. 


\section{Tablo 31}

Yaş Düzeyine Göre BSM Müzik Dersleri Tutum Ortalama Puan Farklllıklarına Yönelik Bonferroni Çoklu Karşılaştırma Testi Sonuçları

\begin{tabular}{|c|c|c|c|c|c|c|c|}
\hline Tutum & Yaş (a) & $\overline{\mathrm{x}}$ & Yaş (b) & $\overline{\mathrm{x}}$ & Ortalama Farkı (a-b) & ss & $\mathrm{p}$ \\
\hline \multirow{8}{*}{ Tutum Ortalama } & \multirow{8}{*}{11} & \multirow{8}{*}{3.15} & 8 & 3.85 & -.69402 & .21831 & $.003^{*}$ \\
\hline & & & 9 & 3.34 & -.18688 & .13731 & .182 \\
\hline & & & 10 & 3.37 & -.21402 & .15318 & .170 \\
\hline & & & 12 & 3.39 & -.24323 & .13731 & .085 \\
\hline & & & 13 & 3.42 & -.26902 & .16582 & .113 \\
\hline & & & 14 & 3.41 & -.25402 & .15318 & .105 \\
\hline & & & 15 & 3.67 & -.51902 & .16582 & $.003^{*}$ \\
\hline & & & 16 & 3.77 & -.61902 & .21831 & $.007^{*}$ \\
\hline
\end{tabular}

Tablo 31 incelendiğinde, yapılan Bonferroni çoklu karşılaştırma testi sonucunda, farklılığın 11 yaș grubundan $\left(\right.$ Ortalama Fark $1_{1-8}=.69402, \mathrm{p}<.05$, Ortalama Fark1 $1_{11-15}=0.51902, \mathrm{p}=<.05$, Ortalama Fark $1_{11-16}=0.61902, \mathrm{p}<.05$ ) kaynaklandığ 1 bulunmuştur.

Bu sonuçlara göre 11 yaş grubunun BSM'deki müzik derslerine karşı tutumlarının özellikle 8,15 ve 16 yaş grupları başta olmak üzere diğer yaş gruplarına göre daha düşük olduğu, tutumları en yüksek yaş gruplarının ise 8,15 ve 16 yaş grupları olduğu söylenebilir.

\section{Sonuç ve Öneriler}

\subsection{Sonuç}

Bilim ve Sanat Merkezlerinde eğitimi verilen müzik derslerinin; Koro, Orkestra, Bireysel Çalg1, Sanat Tarihi, Müzik Teorisi olduğu, öğretim yöntemlerinin ise; Anlatım/soru-cevap, Örnekleme/Tartışma, Performans/Uygulama, Ritim Atölyesi ve Toplu Seslendirme olduğu sonucuna ulaşılmıştır.

Araştırmaya katılan öğrencilerin demografik bilgileri incelendiğinde, öğrencilerin büyük çoğunluğunun kız öğrenci olduğu, en çok katılımın 5. sınıftan sağlandığı, yaş dağılımına bakıldığında öğrencilerin yaşlarının 8-16 arasında değiştiği ve en yoğun yaş grubunu 11 yaş grubundaki öğrencilerin oluşturduğu görülmektedir.

BSM ve okuldaki müzik dersi konularının birbirinden farklılık gösterdiği, BSM'de müzik dersinin daha detaylı öğrenildiği, müzik dersinin sadece enstrüman ağırlıklı değil, müzikle diğer konuların da ağırlığının olacağı şekilde yürütüldüğü, Milli Eğitim'e bağlı diğer okullarda sadece flüt ve melodika öğretilirken, BSM'de bunların dişında da enstrümanların olduğu ve eğitiminin verildiği, sınıfların fiziki şartlarının yeterli olduğu, öğrencilerin enstrüman çalma ve öğrenmede herhangi bir güçlük çekmediği, BSM'de müzik derslerinde işlenen konuların okulda işlenen konulardan farklı ve ilgi çekici olduğu, bu nedenle de öğrencilerin derslerde sıkılmadıkları, öğretmenlerin dersin işlenişinde farklı materyallerden yararlandığı, Türk müzik kültürüne ait eserlerden yararlanıldı̆̆ı, BSM'de çok ileri düzey bir müzik eğitimi verilmediği ve bundan dolayı öğrencilerin öğrenmede güçlük çekmedikleri tespit edilmiştir. Ancak ilerleyen yaşamlarında müziği hobi olarak yapmak istedikleri, meslek olarak seçmek isteyen öğrencilerin sayısının az olduğu ortaya çıkmıştır. Bu sonuca göre ülkemizde, müzik alanına yönelik meslek tanıtım ve özendirme faaliyetlerinin yetersiz olduğunu, bu öğrencilerin müzik alanına yönelik gelecek kaygısı yaşadıklarını söyleyebiliriz.

BSM'de eğitim gören çocukların burayı tercih etme durumları ve derse olan ilgileri incelendiğinde; öğrencilerin büyük çoğunluğunun BSM müzik alanını kendi istekleriyle tercih ettiği, ailenin önerisi ile tercih eden öğrenci sayısının az olduğu, buna bağlı olarak BSM'de görülen müzik dersine karşı tutumların büyük ölçüde olumlu olduğu ve olumsuz tutum sergileyen öğrencilerin ise müzik alanını aile isteği ile seçenler olduğu sonuçları elde edilmiştir.

Öğrencilerin genelinin BSM müzik derslerine yönelik tutumlarının yüksek düzeyde olduğu söylenebilir. Tutum puanları arasında cinsiyet değişkenine göre fark olup olmadığına bakıldığında, kız öğrencilerin SO ve ST değerlerinin erkek öğrencilerden yüksek olduğu, bunun da kız öğrencilerin tutumlarının BSM' de gördüğümüz müzik derslerinin beni kültürel anlamda geliştirdiğine inanırım” maddesi için erkek öğrencilere göre daha yüksek olduğu anlamına geldiği söylenebilir. Başka bir anlatımla, kız öğrencilerin, müzik derslerinin bireyi kültürel anlamda geliştirdiğine olan yaklaşımları erkek öğrencilere göre daha olumludur. Erkek öğrenciler müzik derslerinin kültürel anlamda gelişim sağladığına kız öğrencilerden daha az inanmakta oldukları sonuç olarak elde edilmiştir.

30 kişiden oluşan Kız ve 17 kişiden oluşan Erkek gruplarının tutum ortalama puanları bazında tutum farklılıklarına bakıldığında; tek tek madde bazında tutumlar sadece bir maddede cinsiyet faktörüne göre farklılık gösterse de, tutum ölçeğindeki maddelerin geneli açısından BSM'deki müzik derslerine karşı tutumların cinsiyete göre değişmediği sonucu elde edilmiştir. 
Sınıf düzeyine göre BSM müzik derslerine yönelik tutumlar incelendiğinde, öğrencilerin genelinin müzik derslerine yönelik tutumlarının yüksek düzeyde olduğu, ancak 2. sınıfların tutumlarının daha yüksek olduğu; 8 . sınıfların 2. sınıflara yakın bir tutum sergilediği tespit edilmiştir.

Yaş değişkenine göre tutumları incelendiğinde; 11 yaş grubunun tutumlarının daha düşük olduğu, müzik derslerine istekli bir şekilde çalışmadıkları ve kendilerine olan güvenlerinde müzik dersinin etki yaratmadığını düşündükleri; diğer tüm yaş gruplarının farklılık gösteren bu iki maddede yüksek bir tutum sergilediği, müzik dersleri ile ilgili istekli ve özgüvenli oldukları söylenebilir. 11 yaş grubunun BSM'deki müzik derslerine karşı tutumlarının özellikle 8, 15 ve 16 yaş grupları başta olmak üzere diğer yaş gruplarına göre daha düşük olduğu, tutumları en yüksek yaş gruplarının ise 8,15 ve 16 yaş grupları olduğu söylenebilir.

Genel olarak araştırmada; BSM'lerde eğitimi verilen müzik derslerinin ve burada görev yapan öğretmenlerin öğretim yöntemlerinin yeterli düzeyde olduğu sonucu tespit edilmiştir. Bu durum öğrencilerin büyük bir kısmının müzik dersine ilgilerinin yeterli düzeyde olduğu sonuçlarını da destekler niteliktedir.

$\mathrm{Bu}$ iki okulda öğrenim görmekte olan öğrencilerin çoğunluğunun kız öğrenci olduğu, en çok katılımın 5. Sınıf düzeyinde olduğu ve en yoğun yaş grubunun 11 yaş olduğu belirlenmiştir. Müzik dersi konularının farklılık gösterdiği, sadece enstrüman ağırlıklı olmadığı ama pek çok enstrümanın eğitiminin verildiği bunun yanında, teorik derslerinde verildiği ve öğrencilerin derslerde sıkılmadıkları, öğrenci görüşleriyle tespit edilmiştir. Öğrencilerin çoğunluğunun bu merkezleri kendi istekleriyle tercih ettikleri belirlenmiştir. Öğrencilerin cinsiyet değişkenine göre müzik dersli tutum puanlarının değişmediği belirlenmiştir. Sınıf değişkenine göre 8 . ve 2 . sınıfların müzik dersine karşı tutumlarının diğer sınıflara göre yüksek olduğu tespit edilmiştir. Yaş değişkenine göre 8, 15, 16 yaş gruplarının müzik dersine karşı tutumlarının diğer yaş gruplarına göre daha yüksek olduğu sonuçları elde edilmiştir.

\section{2. Öneriler}

\subsection{1. Öğretmenler ve Ebeveynler için Öneriler}

Araştırma sonuçlarında, bilim ve sanat merkezlerinde eğitimi verilen müzik dersleri ve öğretim yöntemlerinin düzey olarak yeterli olduğu belirtilmektedir. Fakat öğrencilerin farklı değişkenler üzerinden müzik dersi tutumları incelendiğinde; öğretim yöntemlerinin yaş, sınıf ve cinsiyet değişkenlerine göre daha kapsamlı bir şekilde ele alınması ve değerlendirilmesi gerektiği, bu yolla öğrencilerin müzik derslerine olan ilgi düzeylerinin olumlu yönde etkileneceği düşünülmektedir.

Araştırmaya katılan öğrencilerin demografik bilgileri incelendiğinde, öğrencilerin büyük çoğunluğunun kız öğrenci olduğu, en çok katılımın 5. sınıftan sağlandığı, yaş dağılımına bakıldığında öğrencilerin yaşlarının 8-16 arasında değiştiği ve en yoğun yaş grubunu 11 yaş grubundaki öğrencilerden oluştuğu görülmektedir. Bu durum ailelerin, öğretmenlerin ve diğer sorumlu kişi, kurum ve kuruluşların, bu özel çocukların tespitinde ve yönlendirilmesinde her yıl ve her dönem daha etkin rol alması ve yönlendirici olması gerektiği düşünülmektedir.

Araştırma sonuçlarında, bilim sanat merkezlerini kendi isteğiyle değil ailelerinin isteğiyle seçen öğrencilerin müzik dersine karşı tutumlarının olumsuz olduğu tespit edilmiştir. Bu durum bilim sanat merkezlerinde eğitim veren müzik ögretmenleri tarafından ele alınmalı, ailelerle ve çocuklarla görüşülerek sorunlara yapıcı yaklaşımlarla çözüm yolları aranmalıdır.

Bu kurumlarda eğitim alan öğrencilerin müzik yeteneği düzeylerini belirleyerek, ileri seviyeye erişebilecek öğrenciler için ileriye dönük ciddi planlamalar ve çalışma yöntemleri ortaya koymak, sanatsal alanda birey ve ülke gelişimi için büyük önem arz etmektedir. Bu öğrencileri küçük yaşlardan itibaren ülkemize kazandıracağımız birer sanatçı olarak yetiştirebilmek hatta dünya çapında sanatçılar olmalarını sağlamak eğitimcilere düşen önemli bir görevdir.

Üstün yetenekli öğrencilerin ilerleyen yaşamlarında müziği hobi olarak yapmak istedikleri, meslek olarak seçmek isteyen öğrencilerin sayısının az olduğu ortaya çıkmıştır. Bu sonuca göre ülkemizde, müzik alanına yönelik meslek tanıtım ve özendirme faaliyetlerinin yetersiz olduğunu, bu öğrencilerin müzik alanına yönelik gelecek kaygısı yaşadıklarını söyleyebiliriz. Müzik alanı ile ilgili meslek alanlarının çoğaltılması, bu alanlardan mezun olan öğrenciler için iş imkânlarının arttırılması, meslekle ilgili tanıtım ve özendirme faaliyetlerinin yeterli düzeyde yapılması gerekmektedir. Aksi takdirde bu öğrenciler, ülkemiz için büyük bir kayıp olacaktır.

\subsubsection{Araştırmacılar için Öneriler}

Çıkan sonuçları değerlendirdiğimizde bu alanla ilgili araştırma yapılacak başka konular ortaya çıkmaktadır. Bunların bazılarının araştırma yapacak olan meslektaşlarımız için örnek olması, meslektaşlarımızın çalışmalarında bu konuları ele almaları gerekmektedir. 
- Öğrencilerin müzik dersine karşı tutumlarının en üst seviyede olduğu yaş grubunun 8,15 ve 16 yaş olduğu ortaya çıkmıştır. Sınıf olarak değerlendirdiğimizde 2. ve 8. sınıf öğrencileri olduğu görülmektedir. Buradan yola çıkarak bu yaş grubundaki öğrencilerin, diğer yaş gruplarındaki öğrencilere göre müzik dersini daha fazla sevmelerinin sebebi nedir? Müziğe olan ilgilerinin altında psikolojik olarak neler vardır?

- Bilim ve sanat merkezlerinde eğitim vermekte olan müzik öğretmenlerinin sayısı genelde ikidir. Üstün yetenekli öğrencilere, bu öğretmen sayıları yeterli midir? Onlar bağlama, keman piyano ya da gitar dışında enstrümanlar da öğrenmek isteyebilirler mi? 


\section{Kaynakça}

Açıkalın, A. (2009). Okuldaki çocuklarımız (2.Baskı). Pegem Akademi Yayıncılık.

Bakioğlu, A., \& Levent, F. (2013). Üstün yeteneklilerin eğitiminde Türkiye için öneriler.Üstün Yetenekli Ĕ̆itimi Araştırmaları Dergisi, 1(1), 31-44. $\quad$ https://www.researchgate.net/publication/340629577_Ustun Yeteneklilerin_Egitiminde Turkiye_Icin_Oneriler_Suggestions_For_Gifted_Education_in_Turkey

Çamdeviren, Ş. (2014). Bilim ve sanat merkezlerine devam eden üstün yetenekli çocukların anne ve babalarının karşılaştıkları güçlükler (Sakarya ili örneği) (Tez No. 353104) [Yüksek Lisans Tezi, Sakarya Üniversitesi]. Yüksek Öğretim Kurulu Tez Merkezi.

Davis, G. A. (2014). Üstün yetenekli çocuklar ve eğitimi (Işık Koç, M. Çev.). Özgür Yayınları.

Ergün, M. (2014). Eğitim felsefesi. Pegem Akademi Yayıncılık.

Erişti, B. (2012). Üstün yetenekli öğrencilerin öğrenme, öğretme, öğretmenlik mesleği ve öğretmen özellikleri ile ilgili görüşleri. Türk Üstün Zekâ ve Eğitim Dergisi, 2(1), 18-36. https://dergipark.org.tr/tr/download/articlefile/1475919

Fidan, N. (2012). Okulda öğrenme ve öğretme. Pegem Akademi Yayıncılık.

Geçkil, A. (2012). Bilim ve sanat merkezlerindeki (bilsem) laboratuvar yeterliliklerinin ve uygulamalarının değerlendirilmesi (Tez No. 311046) [Yüksek Lisans Tezi, Gazi Üniversitesi]. Yüksek Öğretim Kurulu Tez Merkezi.

Karasar, N. (2005). Bilimsel araştırma yöntemi. Nobel Yayın Dağıtım.

Özdamar, K. (2011). Paket programlar ile istatistiksel veri analizi. Kaan Kitabevi.

Özer Keskin, M., Keskin Samanc1, N., \& Aydın, S., (2013). Bilim ve sanat merkezleri: Mevcut durumları, sorunları ve çözüm önerileri. Üstün Yetenekli Eğitimi Araştırma Dergisi, 1(2), 78-96. https://arastirmax.com/tr/system/ files/dergiler/170002/makaleler/1/2/arastrmx_170002_1_pp_78-96.pdf

Sakar, M. H., \& Maba, A. (2015). Türkiye'de müziksel alanda üstün yetenekli bireylerin eğitimlerine genel bir bakış. The Journal of International Education Science, 2, 110-121. https://doi.org/10.16991/ INESJOURNAL.12

Tunçdemir, İ. (2004, Temmuz). Çoksesli müzikte harika çocuk kanunu'nun Türk müzik kültürüne etkisi: İdil BiretSuna Kan örneği [Konferans Sunumu]. 13. Ulusal Eğitim Bilimleri Kurultayı, Malatya.

Veneziano L., \& Hooper J. (1997). A method for quantifying content validity of health-related questionnaires. American Journal of Health Behavior, 21(1), 67-70. https://www.scienceopen.com/document?vid=8254f3c93a49-4e44-b430-1643adfc84ae

Yağlı, Ş. (2011). Yönetici ve öğretmen görüşleri çerçevesinde bilim ve sanat merkezlerinin yapısı ve yeniden yapılanması (İstanbul Bilsem Örneği) (Tez No. 288149) [Yüksek Lisans Tezi, Yeditepe Üniversitesi]. Yüksek Öğretim Kurulu Tez Merkezi.

Yeşilyurt, S., \& Çapraz, C. (2018). Ölçek geliştirme çalışmalarında kullanılan kapsam geçerliği için bir yol haritas1. Erzincan Üniversitesi Eğitim Fakültesi Dergisi, 20(1), 251-264. https://doi.org/10.17556/erziefd. 297741

Yıldız, H. (2010). Üstün yeteneklilerin ĕgitiminde bir model olan bilim ve sanat merkezleri (BÍLSEMLER) üzerine bir araştırma (Tez No. 279748) [Yüksek Lisans Tezi, Gazi Üniversitesi]. Yüksek Öğretim Kurulu Tez Merkezi. 